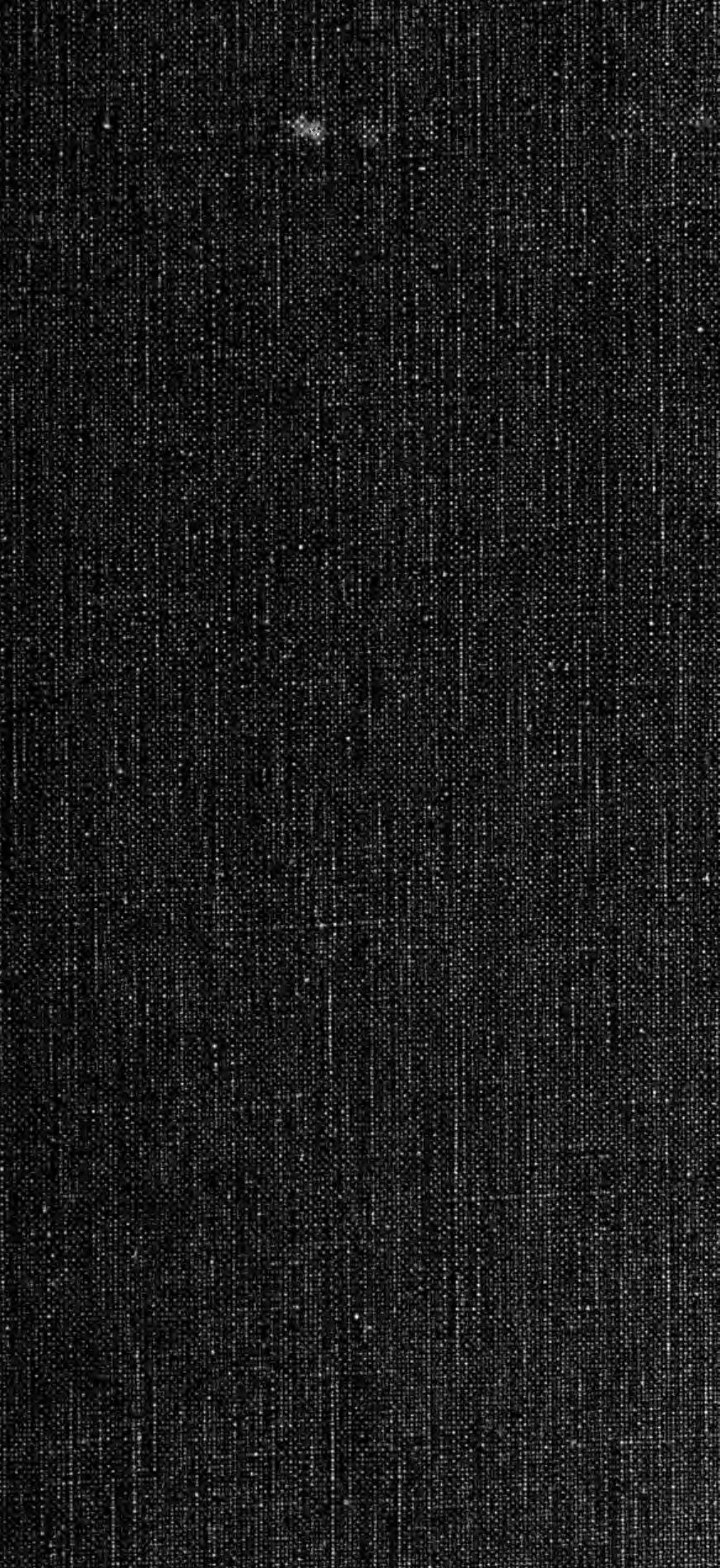



From the collection of the

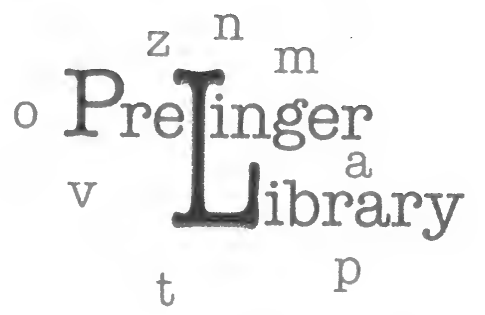

San Francisco, California 2008 





\title{
Essays on Espionage and International Law
}

\author{
QuiNCY Wright \\ Julius Stone \\ Richard A. FALK \\ Roland J. Stanger
}

Edited by Roland J. Stanger With a Foreword by Richard A. FALK

OHIO STATE UNIVERSITY PRESS 1962 
legally excuse himself by pleading that he only executed the orders of his Government, and the latter will never interfere, since it cannot officially confess to having commissioned a spy." ${ }^{2}$ Thus the phenomena of espionage, although often a significant force in international relations, never explicitly ascended in the past to the state-to-state level of traditional international law. That is, the rules of the game allowed a state to employ spies and to prosecute foreign spies that it could catch. These two situations each involved the relation between a government and an individual, whereas international law, at least until recently, was exclusively concerned with the rules binding states in their relations with one another.

Although international law was generally silent about espionage, there was some thought given to the special problem of the treatment of spies during wartime. There was some desire to give minimum protection to spies operating in enemy territory in the course of normal belligerent operations. There does not seem to be such a great difference between a spy and an enemy soldier from the perspective of the target state. Evidently, it seemed rational, as part of the effort to regulate the conduct of hostilities, to offer a captured belligerent spy some slight protection against the wrath of the enemy. This sentiment found its way into the Hague Regulations in the form of a narrow definition of a spy and a requirement of trial before punishment. Significantly, the Hague Regulations do not make belligerent espionage a violation of the laws of war. In fact, as Professor Baxter demonstrates so persuasively, it seems 
preferable not to treat belligerent espionage as a violation of international law. ${ }^{3}$ For belligerent espionage is just one of several constituent forms of belligerency. It expresses a logistic means-end relationship to characteristic belligerent objectives.

It is not nearly so easy to decide about the legal status of peacetime espionage, and it is this that is our primary concern.

Professor Baxter remarks that espionage "is of doubtful compatibility with the requirements of law governing peaceful intercourse of states." ${ }^{4}$ The nazi use of fifth columns and the Soviet development of subversive techniques of infiltration and takeover ${ }^{5}$ suggest the contemporary importance of providing states with some legal protection against foreign espionage. And yet it was the American sponsorship of the U-2 overflights of Soviet territory to obtain aerial photographs of military targets that led to a resurgence of interest in and concern about the international legal implications of espionage. ${ }^{6}$ The United States broke the old rules of the game by explicitly defending its recourse to espionage; in addition, the possibility of nuclear attack from manned aircraft pointed to the destabilizing effect of the U-2 flights. The Powers trial and the breakup of the simultaneous Paris "summit" meeting dramatized the serious political consequences of this kind of espionage under present world conditions. Although the United States apparently acceded to the Soviet demands to terminate the U-2 flights, it has made public its program to achieve the same results by orbiting reconnaisance satellites over Soviet territory. 
A central intellectual problem arises when one tries to think about the status of espionage in the categories set by the traditional dichotomy between peace and war. The cold war and the revolution in military technology make this dichotomy inadequate as a tool of analysis. Thus the problem of espionage in the contemporary world challenges a legal analyst to develop a new conceptual apparatus that is able to cope with the transformed character of international relations.

To encourage this development and to take account of the substantive failure of international law to provide explicit norms regulating espionage, especially during periods of non-belligerency, we devoted the 1960-61 Regional Meeting of the American Society of International Law to the topic of espionage. Professors Quincy Wright, Julius Stone, and Roland Stanger presented their papers on May 12, 1961, in the Law School Auditorium of the Ohio State University College of Law, with Dean Robert J. Nordstrom presiding. The wellattended meeting was enlivened by the rich diversity of outlook expressed by these distinguished speakers. These essays concentrate upon the existence and development of international legal standards applicable to aerial espionage performed in the course of the cold war. This focus follows naturally from progress in space technology, and particularly from the failure of the U-2 and its imminent, provocative replacement by observational satellites capable of photographing and observing the Soviet Union. This subject matter is important today because it bears directly and ambiguously upon the hopes for disarmament and the fears of a nuclear 
surprise attack. Does, for instance, space espionage inhibit a Soviet surprise attack or facilitate a United States surprise attack? This question highlights the urgent relevance of these new forms of espionage for the peace and security of mankind.

This was the sixth consecutive year in which the College of Law has cosponsored a regional meeting of the American Society of International Law on the campus of the Ohio State University. As was the case last year, the 1961 conference and subsequent publication were made possible by the generous financial support of the Mershon Center for Education in National Security. The planning of the conference was greatly assisted by the continuing co-operation of Robert J. Nordstrom, chairman of the Mershon Center. As in prior years, the leadership and participation of Professor Roland J. Stanger have been indispensable to the success of all phases of the 1961 regional meeting program.

Ruchard A. FALK

1. Singer, Three Thousand Years of Espionage, vii (1948).

2. 1 OpPenheIM, INTERNATIONAL LAw, $\$ 455$ at 862 (8th ed. Lauterpacht ed. 1955).

3. Baxter, So-Called "Unprivileged Belligerency"-Spies, Guerrillas, and Saboteurs, 28 BRIT. Yв. INT'L L. 322, 329-333 (1951); but see ex parte Quirin, 317 U. S. 1 (1942); also Hyde, Aspects of the Saboteur Cases, 37 Am. J. Int'L L. 88, 90 (1943).

4. Id. at 329 . 
5. For survey of Soviet practice, see DaLlin, Soviet EsPIONAGE (1955).

6. Wright, Legal Aspects of the U-2 Incident, $54 \mathrm{Am}$. J. INT'L L. 836 (1960); see also the introductory comment of Professor Berman in The Trial of the U-2, i-xxx (1960). 


\section{Contents}

Espionage and the Doctrine of Non-Intervention in Internal Affairs

Quincy Wright

Legal Problems of Espionage in Conditions of Modern Conflict

Julius Stone

Space Espionage and World Order: A Consideration of the Samos-Midas Program

Richard A. FALK

Espionage and Arms Control

Roland J. Stanger

83 



\section{ESSAYS ON}

ESPIONAGE AND INTERNATIONAL LAW 

Espionage and the Doctrine of

\title{
Non-Intervention in \\ Internal Affairs
}

Quincy Wright*

\begin{abstract}
T
I HE BASIC PRINCIPLE of international law is that of respect by each sovereign state for the territorial integrity and political independence of others. This principle was generally accepted in Europe after the inexpediency of religious war had been demonstrated by the devastations of the Thirty Years War, and the axiom "Cuius Regio Eius Religio" had been accepted as the basis of the Peace of Westphalia in 1648. ${ }^{1}$ In spite of renewed efforts to put ideology ahead of territorial sovereignty at the time of the French Revolution and the Russian Revolution, this principle is still accepted in the United Nations Charter based on the "sovereign equality of all its members," requiring abstention from "the threat or use of force against the territorial in-

- Professor Emeritus of International Law, University of Chicago, and Professor of Foreign Affairs, University of Virginia.
\end{abstract}


tegrity or political independence of any state," and prohibiting "intervention in matters which are essentially within the domestic jurisdiction of any state" (Article 2 ). The Latin American states have always accepted this principle, and the United States joined them in asserting it in the Montevideo Convention of 1933 on the rights and duties of states. All the American states emphasized, in this and other inter-American Treaties, the duty of non-intervention-direct or indirect-in either the internal or external affairs of other states. ${ }^{2}$ President Eisenhower proclaimed it when he said in April, 1953: “Any nation's right to a form of government and an economic system of its own choosing is inalienable. Any nation's attempt to dictate to other nations their form of government is indefensible." ${ }^{3}$ Prime Minister Khrushchev accepted this principle when he proclaimed the doctrine of peaceful coexistence for all sovereign states." Prime Ministers Nehru and Chou En-lai and the representatives of other Asian and African states accepted the Panch Shila at the Bandung Conference of 1955 calling for mutual respect, nonaggression, non-intervention, equality, and peaceful coexistence. $^{5}$

It is clear that intervention, defined as dictatorial interference in the internal or external affairs of another state, cannot be reconciled with the basic principles of international law. Intervention invades the territorial integrity and denies the political independence of another state. However, states that are in continuous and continually increasing contact with one another, as means of communication, transportation, and pressure 
develop with the march of science and technology, find their interests affected by the acts of others and attempt to influence those acts. They do so by internal development of culture, economy, and power; by achievements in technology, science, literature, and the arts; by international communication utilizing radio, press, popular periodicals and technical journals; by the travel and trade of their citizens; and by official utterances, legislative action, and diplomatic correspondence. International law is faced with the issue: When does proper influence become illegal intervention?

In the definition of intervention, stress has been laid on the words dictatorial and interference. Persuasion is said to be legitimate; coercion, dictatorial and illegitimate; but the line between the two may be vague. Military invasion is certainly coercive, but what of economic embargo, secret infiltration, peremptory diplomatic notes, or incitement to subversion by radio? Public statements of policy or purpose by a government are said to be legitimate; subversive or inciting actions by, or with complicity of, a government within another state's territory or affecting another state's officials are considered interference and illegitimate. But here again the line is not easy to draw. Officially supported hostilities, assassinations, or incitements; infiltration of government agencies; bribery of officials; espionage into official secrets; and other acts within a state's territory forbidden by its laws-these are doubtless interference; but what of expressed or implied threats in public pronouncements of policy by a government? What of the publications, speeches, and conversations 
of an inciting character by foreign travelers? What of observations and reports by diplomatic attachés and citizens instructed by another government? The Supreme Court of the United States has found it difficult to distinguish legitimate uses of the freedom of speech and press from seditious, subversive, libelous, or inciting utterances or expositions. ${ }^{6}$

While it is difficult to distinguish dictatorial interferences from proper influence and exposition, it is even more difficult to distinguish the internal affairs and foreign policy of a state from its acts or utterances which so affect the rights and interests of another state that they can be regarded as of international concern, and as justifying interference, even dictatorial interference, by the state affected.

A state can undoubtedly protest acts which it deems in violation of its rights and can make representations or even resort to economic retorsions against acts it deems adverse to its interests. It can go further and conduct reprisals not involving the use of armed force to rectify injuries arising from violation of its rights, if the available peaceful means of adjustment or reparation have been exhausted without results, and the means of reprisal are no more serious than the injury complained of. Finally, a state can use armed force to defend its territory or armed forces against armed attack, to assist others that are victims of such attack, or to assist the United Nations "to maintain or restore international peace and security" in case of "threat to the peace, breach of the peace, or acts of aggression" or to enforce a judgment of the International Court of 
Justice. But difficulties of precise definitions again rise. Can a state initiate reprisals on the basis of its own judgment that it has suffered from a breach of international law? How can it be determined that reprisal measures are, in fact, designed to rectify wrongs? Who determines when peaceful remedies have been exhausted? By what criteria can the relative seriousness of the initial injury and the reprisal measures be determined? Can defensive measures be taken preventively in case of immediate threat of invasion? Can they be taken to protect citizens abroad in danger of their lives? How does the United Nations determine when civil strife threatens international peace? Under what circumstances can the United Nations intervene to protect the "human rights" of the nationals of a state or secure the "self-determination" of a colony? May states intervene for such humanitarian purposes if another state in its internal administration is guilty of atrocities which "shock the conscience of mankind"?

These questions raise issues requiring careful analysis if the broad principles of international law are to be applicable in practice. ${ }^{7}$

Some writers have been so impressed by the circumstances which seem to justify intervention that they have elevated "intervention" into a normal procedure of international law to rectify wrongdoing. Thus Stowell, in a comprehensive study of the question, concludes that "intervention in the relations between states is the rightful use of force, or the reliance thereon, to constrain obedience to international law." Though recognizing the serious effect of intervention, in that "it 
leaves the weak without the means to bring the strong transgressor to justice," he is convinced that international law must depend mainly upon "the action of the separate states to secure redress for their own injuries." ${ }^{8}$ While this point of view may have had some justification in an earlier stage of international law, it is clearly contrary to the United Nations Charter, which seeks to abolish forcible self-help in international relations except in individual or collective self-defense against armed attack, and relegates other law enforcement activities to collective action through the United Natiops. ${ }^{9}$

Others, instead of attempting to justify intervention under international law, conclude that international law is not applicable at all in time of cold war. Cold war, they say, is more like hot war than like peace, and traditional international law has permitted each belligerent during a state of war to invade and occupy the territory of its enemy, to destroy its armies, to subvert its government, to incite its population, to establish blockades and other economic coercions, to carry on propaganda and intimidation, and, in general, to pay no respect to the territorial integrity or political independence of its enemy. ${ }^{10}$

Others go further and say that law has no applicability to international affairs under any circumstances. International law they consider an illusion, declaring that international relations are relations of power in which expediency is the only guide.

If such positions are taken, the question posed by the title of this paper is irrelevant. We shall, therefore, as- 
sume that there is a "doctrine of non-intervention," that it is a legal doctrine, that a state of war does not exist between the United States and the Soviet Union, and that the subject under discussion is the lawfulness of espionage on these assumptions.

We must first be clear about the sources of international law. Attitudes toward that law may be divided according as people consider themselves "realists" asserting that the immediate material state of affairs cannot be changed by ideas but only by force, or as "idealists" asserting that ideas and values can, in time, greatly influence present material conditions, that men and governments act from beliefs, not from capabilities, and that wars are made in the minds of men, not in technological equipment. ${ }^{11}$

A balance between these two positions has been maintained by most international lawyers. Law differs from sociology in that it formulates the values, not the behavior, of the community. The two are related because behavior provides some evidence of values, and values influence behavior; but the two are not identical. The behavior of some members of a community at most times, and of most at some times, may be contrary to the generally accepted values of the community. Jural law, therefore, differs from sociological law in that it may be violated. Practice gives evidence of law only when it manifests custom, reflecting a subjective sense of right or obligation. In conformity with this general conception, international law reflects not the values of one nation, but the consensus of values which all nations profess. Because of the decentralized character 
of the society of nations, the consequent imperfection of the sanctions of international law, and the absence of an international legislative authority, international law is closer to behavior than are most systems of municipal law. Nevertheless, we must assume that it is law and that, to discover its rules, we must seek the values which states generally accept, and give weight to their practices only insofar as they provide evidence of that acceptance.

The statute of the International Court of Justice declares that the court, to decide cases in accordance with international law, shall apply:

(a) international conventions, whether general or particular, establishing rules expressly recognized by the contesting states; (b) international custom, as evidence of a general practice accepted as law; (c) the general principles of law recognized by civilized nations; (d) . . . judicial decisions and the teachings of the most highly qualified publicists of the various nations, as subsidiary means for the determination of rules of law (Article 38).

The use of the words recognized and accepted in this formulation emphasizes the importance of the subjective factor in appraising the value of material evidences of the law in conventions, practices, principles, precedents, and commentaries.

What is the status of peacetime espionage in accord with these sources? Very little has been said about it in the books. Espionage is a term of art in the law of war. The Hague Convention of 1907 on the laws and customs of war on land says: 
An individual can only be considered a spy when, acting clandestinely, or on false pretenses, he obtains, or endeavors to obtain, information in the zone of operations of a belligerent with the intention of communicating it to the hostile party.

Thus, soldiers not wearing a disguise, who have penetrated into the zone of operations of a hostile army for the purpose of obtaining information, are not considered spies. Similarly, the following are not considered spies: soldiers and civilians, carrying out their mission openly, intrusted with the delivery of dispatches intended either for their own army or for the enemy's army. To this class belong likewise persons sent in balloons for the purpose of delivering dispatches, and, generally, of maintaining communications between the different parts of an army or a territory.

A spy, taken in the act, shall not be punished without previous trial.

A spy who, after rejoining the army to which he belongs, is subsequently captured by the enemy, is treated as a prisoner of war, and incurs no responsibility for his previous acts of espionage (Articles 29-31).

Text writers generally recognize that while a spy, if captured in the act, can be executed after trial, his activities are not dishonorable, his government is not violating law in sending him, and his act is not, therefore, a war crime. Espionage is a legitimate belligerent operation peculiar in that it involves considerable risk to the spy, but the same is true to a somewhat lesser degree of soldiers who engage in normal belligerent operations.

Espionage, the essence of which is the clandestine character of the activity and the false pretenses or dis- 
guise of the individual who engages in it, is to be distinguished from observation by a scout in uniform or from reconnaissance by an aviator, under cover of darkness or distance, but not in secret, under false pretenses, or in disguise. The scout or the aviator, if captured, are entitled to the normal treatment of prisoners of war.

The legitimacy of espionage in time of war arises from the absence of any general obligation of belligerents to respect the territory or government of the enemy state, and from the lack of any specific convention against it. The deception involved resembles that in stratagems or ruses de guerre and differs from violations of specific conventions like those of the flag of truce, red cross emblems, and armistices, all of which constitute "perfidy" and are forbidden by the law of war.

In time of peace, however, espionage and, in fact, any penetration of the territory of a state by agents of another state in violation of the local law, is also a violation of the rule of international law imposing a duty upon states to respect the territorial integrity and political independence of other states. Each state has the right to make and enforce law within its territory, except insofar as it is under positive obligations of international law, such as those to respect the immunities of diplomatic officers, foreign warships, foreign forces, and other foreign agencies which it has permitted in its territory; to permit innocent passage of foreign vessels in its territorial waters; not to deny justice to aliens whom it has admitted to its territory; and to observe treaties which it has ratified. There is no rule of interna- 
tional law which forbids a state to punish individuals who seek to obtain classified documents, who penetrate forbidden areas, who fly over its territory without permission, or who engage in seditious or other activities which it has made illegal. It belongs to each state to define peacetime espionage, sedition, subversion, sabotage, incitement, and conspiracy as it sees fit, and it is the duty of other states to respect such exercise of domestic jurisdiction. Thus any act by an agent of one state committed in another state's territory, contrary to the laws of the latter, constitutes intervention, provided those laws are not contrary to the state's international obligations. Intervention by unlawful acts in another state's territory may be divided into direct or open intervention, such as armed invasion, and indirect or subversive intervention involving secret activity. Since the government responsible for the latter type of action seldom acknowledges its responsibility but allows the agent, if caught, to be punished without protest, such incidents are not usually the subject of international discussion. Numerous communist spies, saboteurs, or other agents have been detected and punished in Western countries, but the communist government responsible for sending them has never interfered unless the individual was a diplomatic personage. In this case it has claimed diplomatic immunity for the individual, and if that claim is acknowledged, the individual is not punished but declared persona non grata and required to leave the country. In such cases the official character of the individual is known, and the incident usually results in an official protest to the send- 
ing state by the receiving state. The peculiarity of the U-2 incident of May 1, 1960, was the acknowledgment of responsibility by President Eisenhower, which clearly gave the Soviet Union grounds for official protest. There can be no doubt of the competence of the Soviet Union to deal with the aviator, Francis Powers, in accord with its own laws. Although Powers was an agent of the United States government, he was not lawfully within Soviet territory, and so was not entitled to any immunity under international law. ${ }^{12}$ The immunity claimed by Great Britain for Alexander McLeod in the Caroline incident of 1838 arose from the fact that McLeod was not only a soldier acting under British orders, but also lawfully within American territory, because the invasion was justified by the necessity for self-defense. ${ }^{13}$

Intervention, however, goes beyond action by one state in the territory of another. Governments are obliged to refrain from inciting propaganda, libelous utterances, or other acts intended to upset the government of another state. It would appear that the proclamation by the President of the United States of "Captive Nations Week," under authority of an act of Congress, was of this character, ${ }^{14}$ as was the President's statement of sympathy for rebels seeking to upset the government of President Castro in Cuba. ${ }^{15}$ It is within the domestic jurisdiction of each state to establish its government by its own internal processes and to change that government, whether by peaceful or violent means. Each state enjoys the "right of revolution" so long as the exercise of that right by its people does not threaten the peace and security of other states. Consequently, official acts 
of other governments assisting rebels, or interfering in behalf of either a recognized government or the insurgents in time of civil strife, constitutes forbidden intervention. This is expressly recognized by the interAmerican convention of 1928 on Civil Strife. ${ }^{16}$

Free governments have held that, while official acts of the kind described constitute illegal intervention, this is not true of private acts within their territory. They consider themselves under no obligation to prevent propaganda hostile to foreign governments by private individuals in their territory. Such activities they consider within the proper guarantees of freedom of speech and press. Autocratic governments, on the other hand, have often censored such activities within their territory and have attempted to gain recognition of an international duty of other governments to do likewise. There have indeed been international conventions requiring censorship of radio communications of subversive character, and punishment of acts of terrorism against foreign governments. It is also true that governments are obliged to exercise due diligence to prevent military expeditions from leaving their territory to operate against other governments. Failure in this regard, as well as launching of official military expeditions, constitutes aggression, which is explicitly forbidden by the United Nations Charter. The United States may have been guilty of such want of due diligence in the Cuban incident of April, 1961. In general, however, there appears to be a distinction between hostile acts by a government and hostile acts by a private individual. The latter do not constitute interven- 
tion unless there has been government complicity or, in the case of military action, government negligence.

The problem of negligence is closely related to the sic utere tuo rule, which imposes liability upon a state for incidents in its territory injurious to another state, such as the use of river waters by an upper riparian in such a way as to deprive the lower riparian of a fair share of the stream, the operation of a factory which sends noxious fumes across the border, or the launching of a satellite or missile which falls in another state and causes serious damage to the latter. In such cases liability may go beyond that for willful act or even negligence and exist without fault. The responsibility arises from the inherently dangerous character of the activity.

In view of these general rules of international law, are there any special conditions justifying peacetime espionage? Efforts have been made to justify such action by the United States in the Soviet Union because of: (1) a general practice of espionage by all states, (2) the necessity for self-defense, (3) the necessity to maintain the balance of power, (4) the unreasonableness of Soviet objection in view of its own espionage activities, and (5) the virtue of espionage or other types of intervention against communism/ Consideration will be given to each of these alleged justifications.

1. Although very few writers on international law have discussed peacetime espionage, the well-known British jurist, Lassa Oppenheim, writes as follows:

Spies are secret agents of a state sent abroad for the purpose of obtaining clandestinely information 
in regard to military or political secrets. Although all states constantly or occasionally send spies abroad, and although it is not considered wrong morally, politically, or legally to do so, such agents have, of course, no recognized position whatever according to international law, since they are not agents of states for their international relations. Every state punishes them severely when they are caught committing an act which is a crime by the law of the land, or expels them if they cannot be punished. A spy cannot be legally excused by pleading that he only executed the orders of his government and the latter will never interfere, since it cannot officially confess to having commissioned a spy. ${ }^{17}$

The suggestion that, because of the frequency of the practice, sending spies is not "legally" wrong seems to be contradicted by the last part of this quotation. Why cannot a government "officially confess to having commissioned a spy," unless it is legally wrong? This would appear to be a case in which frequent practice has not established a rule of law because the practice is accompanied not by a sense of right but by a sense of wrong.

2. After the U-2 incident, the United States sought to defend itself by asserting that such activity was necessary for self-defense. The United States, as an open society, presents every opportunity to the Soviet Union to detect any preparations for surprise attack, but in the closed society of the Soviet Union, the United States had to utilize aerial espionage for this purpose, especially after the Soviet Union had refused to accept the "open skies" proposal made by President Eisenhower 
in the Summit Conference of 1955. President Eisenhower said in reference to the U-2: "No one wants another Pearl Harbor," and Secretary of State Herter said:

It is unacceptable that the Soviet political system should be given the opportunity to make secret preparations to face the free world with the choice of abject surrender or nuclear destruction. The Government of the United States would be derelict to its responsibility, not only to the American people, but to free peoples everywhere if it did not, in the absence of Soviet cooperation, take such measures as are possible unilaterally to lessen and to overcome this danger of surprise attack. ${ }^{18}$

International law, however, permits military selfdefense only in case of armed attack or at least immediate threat of armed attack. The danger apprehended by the United States flowed from an interpretation of Soviet policy and intent, not from an immediate threat of attack. Furthermore, if the United States planned no first strike with nuclear weapons, as it has repeatedly asserted, it is difficult to see what direct defense value there would be in aerial observations. Although they might add to the effectiveness of a second strike, the information so gained, if it remained secret, would not have deterrent value.

American courts have held that a single individual with a military purpose, such as espionage or observation from aircraft, may constitute a "military expedition or enterprise" punishable under United States criminal law, if he proceeds from American territory 
with the intent to enter foreign territory. ${ }^{19}$ While a reconnaissance plane may carry a bomb of great destructive power, and its overflight may therefore be regarded as an armed attack by the state overflown, it seems doubtful whether the dispatch of such a plane, when not actually armed but intended merely for reconnaissance, can be regarded as an act of aggression. It is, however, an act of intervention, and cannot be justified on grounds of self-defense except in response to an actual attack or immediate threat of armed attack. ${ }^{20}$

3. George Schwarzenberger writes in an article entitled "Hegemonial Intervention":

While the nuclear stalemate between the worldcamps lasts, each side may claim with a greater or lesser degree of justice that, by keeping its own strength unimpaired, it makes its own indispensable contribution to the maintenance of world peace. Thus, in the minds of the world-camp directors and their publicity departments, intervention for the purpose of maintaining the status quo in the relative strength of the two camps is easily equated with serving the interests of world peace. ${ }^{21}$

However, he regards this argument as political rather than legal, recognizing that justification cannot be found in international law or the United Nations Charter, and that "however circumspectly handled, hegemonial intervention is always an instrument of international politics that involves taking calculated risks." $\mathrm{He}$ thus appears to endorse the well-known position of Sir Vernon Harcourt that "intervention is a high and sum- 
mary procedure which may sometimes snatch a remedy beyond the reach of law. . . . Its essence is illegality, its justification is its success." 22

4. Ambassador Lodge and Secretary Herter sought to justify the U-2 flight on the ground that the Soviet government was engaged in espionage on an even larger scale than the United States. Ambassador Lodge cited eleven cases in which Soviet spies had been unmasked in the United States since the death of Stalin, and said that there had been 360 convictions of Russian espionage agents in courts of free-world countries, and that these represented only a minor proportion of the cases in which Soviet espionage activities had been actually involved. ${ }^{23}$ This $t u$ quoque argument has had a certain recognition in the equitable principle of "clean hands," "he who seeks equity must do equity." Judge Manley O. Hudson invoked this principle in his opinion in the River Meuse Case in the International Court of Justice, defining it as follows:

Where two parties have assumed an identical reciprocal obligation, one party which is engaged in a continuous non-performance of the obligation should not be permitted to take advantage of a similar non-performance of the obligation by the other party. ${ }^{24}$

While this equitable principle is not normally applicable in criminal law, the Nuremburg Tribunal refused to proceed with indictments against Admirals Raeder and Doenitz, accused of ordering the sinking of merchant vessels by submarines at sight, after evidence had 
indicated that British and American Naval authorities had done the same thing during World War II. In the particular incident of the U-2, the Soviet representative, Gromyko, sought to refute this argument by implying that ordinary espionage and aerial reconnaissance are so different that this "clean hands" principle did not apply. It is clear that the nature and gravity of delinquencies must be similar, if not identical, to justify invocation of this principle. An over-flying plane is more capable of carrying a bomb of great destructiveness than is an ordinary secret agent. The United States, while calling attention to reconnaissance by Russian ships and espionage by agents, did not assert any cases of Soviet aerial reconnaissance, although it subsequently disclosed that a Soviet diplomatic officer had hired an American aviator to photograph strategic bases in the United States. In principle, all peacetime espionage in foreign territory is illegal; but when all are engaging in it, it seems unreasonable to single out one state for utilizing a particular form of espionage, even though that form carries possibilities of hostile action going beyond espionage. The difference should not be exaggerated. Although a reconnaissance airplane may carry bombs, a secret agent may plant a bomb and engage in various forms of sabotage. Therefore, while this argument is of somewhat doubtful legal value, it undoubtedly has much moral cogency.

The value of the argument may be even greater when third states are involved. Richard Falk, referring to the Spanish Civil War, proposes a rule "that interventionary contacts, once established, invite other 
states to counter-intervene, at least to an offsetting degree." ${ }^{25}$ If, as illustrated in the Spanish Civil War, states favorable to one side observe the rule of non-intervention in civil strife, and those favorable to the other side do not, the latter is likely to win. It should be noticed, however, that such counter-intervention tends to develop the civil strife into general international war. For this reason, the Charter permits intervention only by the United Nations in such circumstances and the United Nations has called upon all states not to intervene, as illustrated in the Security Council's Resolution of February, 1961, in the Congo situation. This situation suggests the value of the rule of international law forbidding intervention in civil strife by states individually. As Falk points out, "considerations influencing action by an international organization are quite different from those that should be available to a single state." ${ }^{26}$

Under present circumstances, it does not appear that a general rule justifying counter-intervention is expedient. Rather, action should be taken through the United Nations to terminate the original intervention.

5. Richard Falk further points out that "the official United States view is to regard the Caracas Resolution as a revival of the Monroe Doctrine, shifted from a unilateral to a multilateral axis, and directed against Communism rather than Colonialism." ${ }^{27}$ After noting policies in sections of the world other than Latin America, he concludes: "The United States' recognition practice tends to be as interventionary as possible whenever Cold War issues are involved." ${ }^{28}$ There can be no doubt 
that these statements are borne out by the Caracas and other Latin American declarations against communism, the Truman and Eisenhower Doctrines, the fact that the United States limits SEATo interventions to those against communism, and the non-recognition of mainland China, North Korea, North Vietnam, and East Germany. They are, however, statements of American policy and not of international law. The United Nations Charter recognizes the sovereign equality of all members, whatever their ideologies. Thus it does not appear that espionage or any other form of intervention can be legally justified on the ground that it is carried on as part of a crusade against communism.

Even as a policy, the suggestion that communism, which now governs over one-third of the human population, is a doctrine so wicked that illegal means can be used against it is difficult to support. Such a policy resembles those which supported continuous hostility between Christendom and Islam in the Middle Ages, between Catholicism and Protestantism for a century before the Peace of Westphalia, and between absolute monarchs and the principles of the American and French Revolutions in the late eighteenth century. Modern international law and the United Nations Charter have attempted to prevent exactly such policies, which could be in the future as they have been in the past, a major cause of universal war.

It therefore seems that in the modern world, even more than in the earlier periods mentioned, ideological war ought to be avoided. The question of which ideology is the best for a given people cannot be settled by 
outside intervention but only by the people involved, through revolutionary action or, preferably, by discussion in a free forum of public opinion. For the world as a whole, such a free forum may be difficult to achieve, but to achieve it should be the object of states, as it is of the United Nations. To this end, the rule of international law, requiring mutual respect by states for the territorial integrity and political independence of other states, should be observed. Illegal intervention should be condemned, and, where it occurs, collective action through the United Nations, or, in the Americas, through the Organization of American States, should be sought.

Such a policy is particularly important for democracies because both experience and analysis show that in a competition for power, particularly in using subversive methods, dictatorships have great advantages. They can act rapidly, secretly, and effectively. They can divert resources away from the production of consumer goods to the building of power. They can respond to requests for assistance by underdeveloped countries immediately, without congressional debate and without apparent political strings. In the present world, the communist powers have the advantage of interior lines and can threaten, mobilize or attack successively at different points on their long periphery. Because of these advantages, manifested in the continuous increase of the relative power of the communist states since World War II, these states are not eager to accept the rule of law. ${ }^{29}$ Yet Khrushchev's demand for peaceful coexistence and competition may be genuine. He probably 
does not want nuclear war, which would destroy the fruits of Soviet economic development. His people clearly do not want the suffering of another world war. He may believe that his model will eventually prove acceptable to the poor people of Asia, Africa, and Latin America, and even to the West, without the support of military aggression or subversive intervention. If he believes, as Walter Lippmann says he does, in the inevitable triumph of communism in the deterministic march of history, he may not want to run the risk that such methods will eventuate in war. Finally, he may fear that in a general war, whatever might happen to the Western world, China, rather than Russia, would emerge as the leader of the communist world.

It would appear, therefore, that, difficult as may be the task, maintenance of the rule of international law against intervention of any kind may not be impossible. The West would certainly gain by a world in which states competed in a forum of opinion stabilized by law and in which each could present the values of its model of social, economic, and political organization for others to imitate. In such a world, democracy would have a fair chance to survive. Its survival is doubtful in a jungle world which places a premium on skills in subversion, infiltration, espionage, guerrilla warfare, nibbling aggression, and other forms of intervention in which totalitarian dictatorships have so great an advantage. Deciding what steps can be taken to "make the world safe for democracy" requires study, less in the technology of deterrence than in the psychology of tension reduction. By avoiding interventions themselves and 
utilizing international organizations to frustrate interventions by others, by pursuing policies of defense without provocation, and conciliation without appeasement, democracies may win confidence in their peaceful intentions in the uncommitted and even in the communist world. An atmosphere favorable to armament negotiation may emerge and the peace of mutual terror may in time give way to a peace of mutual confidence that law will be respected.

There can be no guarantee that this will happen. The hope that it may rests on the belief that people individually, in the long run, prefer survival and freedom to ideological allegiance, and that peoples collectively prefer self-determination and prosperity to domination. The alternative of continual competition in arms, propaganda, subversion, and espionage between free democracies and totalitarian autocracies seems almost certain, in the atomic age, to spell the end of democracy, if not of humanity.

1. Wright, International Law and Ideologies, 48 Aм. J. INT'L L. 616 ff. (Oct. 1954).

2. International Legislation (Hudson ed.), Vol. 4, p. 2418, Vol. 6, pp. 450, 623, 628, Vol. 7, p. 578; Aм. J. INT'L L., Vol. 46, p. 46 (Supp. 1952), Vol. 48, p. 123 (Supp. July 1954); Wright, Intervention and Cuba in 1961, in Proceedings of the American Society of International LAW (1961) p. 2.

3. 28 Dep't State Bull. 599 (1953).

4. 38 Foreign Affairs $3 \mathrm{ff}$. (1959).

5. Wright, Asian Experience and International Law, in 1 INTERNATIONAL STUdiES 85 (Indian School of International Studies, July 1959). 
6. Dennis v. United States, 341 U.S. 494 (1951); Pritchett, Civil Liberties and the Vinson Court $71 \mathrm{ff}$. (University of Chicago Press, 1954).

7. Wright, The Prevention of Aggression, 50 Aм. J. INT'L L. 526 (July 1956).

8. STOWELl, INTERVENTION IN INTERNATIONAL LAW vi, 46 (Washington, D.C., John Byrne, 1921); InTERNATIONAL LAW 72 (N. Y., Henry Holt, 1931).

9. Julius Stone attempts to interpret the United Nations Charter so as to permit military reprisals, such as those undertaken by Great Britain and France at Suez in 1956 and condemned by the United Nations. See AgGression AND World Order (New York, 1958).

10. George Sokolsky, in a column in the Washington Post, May 10, 1961, writes: "The time is rapidly coming when the United States will weary of such semantic expressions as Cold War and will recognize that war has many different devices and that World War II never ended but has continued in different forms." He overlooks the fact that in World War II the Soviet Union was an ally, not an enemy of the United States.

11. The meanings of the terms "realism" and "idealism" are highly controversial. See Wright, Realism and Idealism in International Politics, 5 WORLD POLITICs $116 \mathrm{ff}$.

12. Wright, Legal Aspects of the U-2 Incident, 54 Aм. J. INT'L L. 836 ff. (Oct. 1960).

13. Moore, International Law Digest, Vol. 2, p. 409 ff., Vol. 6, pp. 261, 1014.

14. Wright, Subversive Intervention, 54 AM. J. INT'L L. $521 \mathrm{ff}$. (July 1960).

15. Wright, Intervention and Cuba in 1961, ProceEdINGS OF THE AMERICAN SOCIETY OF INTERNational LAW (1961) p. 2.

16. 4 International Legislation 2418 (Hudson ed.).

17. Oppenheim, 1 International LAw, $\S 455$ (London, Longmans, 3d ed. 1920).

18. 42 Dep't State Bull. 816 (1960). 
19. United States v. Sander, 241 Fed. 417, 419 (1917); Hackworth, 7 International Law Digest 399.

20. Wright, Legal Aspects of the U-2 Incident, 54 Aм. J. INT'L L. 846.

21. Schwarzenberger, Hegemonial Intervention, 12 YEAR Book OF World AfFarrs 261 (London Institute, 1959).

22. "Historicus," Letters on Some Questions of InterNational Law 41 (London, 1863).

23. Ambassador Henry Cabot Lodge, Jr., in United Nations Security Council. See Wright, Legal Aspects of the U-2 Incident, 54 Aм. J. INT'L L. 847, 851.

24. P.C.I.J., ser A/B No. 70, p. 77; 4 World Court RePORTs 232 (Hudson ed.).

25. Falk, The United States and the Doctrine of Nonintervention in the Internal Affairs of Independent States, 5 How. L. J. 169 (June 1959).

26. Id. at 170 .

27. Id. at 182 .

28. Id. at 185 .

29. A. Ravenholt, an experienced reporter in southeast Asia, after pointing out some "obvious disasters" of United States "covert operations" in that area and the likelihood of further mistakes because they are "built into the system," concludes: "While many of these difficulties may be the United States' growing pains in a new dimension of the world struggle, still unanswered is the question of the role and management of such secret activity by a democracy." Washington Post, May 10, 1961. 


\title{
Legal Problems of Espionage in
}

\section{Conditions of Modern Conflict}

\author{
Julius Stone*
}

$\mathrm{M}_{\mathrm{r}}$

R. CHAIRMAN, let me thank you for your kind words and say how grateful I am for the opportunity of being here with you again. May I also thank my friend Quincy Wright for his very moving address with so little of the drive of which I found myself in agreement. I wish, Mr. Chairman, that you hadn't given me any advance subject at all. I could then have concentrated on delivering a full bill of particulars as to the respects in which I find myself in disagreement (of course with great trepidation) with this very distinguished American international lawyer. Or perhaps it is fortunate, nevertheless, that you gave me other directives so that I cannot really attempt to say what I know it is my duty through you to say to Quincy Wright. And,

"Challis Professor of International Law and Jurisprudence, University of Sydney, Australia. 
of course, it is entirely beyond my powers to show how completely wrong on the basic matter he really is.

Listening to him did, indeed, leave me thinking about my favorite young lady from Melbourne. Melbourne is a very much primmer city, Mr. Chairman, than Sydney. Young ladies are well brought up, with the proper restraints, and this young lady was brought up in a very fine family, who lived in a very excellent home in very beautiful grounds. Her bedroom led out through French doors onto a lovely lawn; and one morning as she slept there a dark and very handsome stranger came in through the French windows without saying a word. She was startled, of course, and was awakened by his arrival. He came up to her bedside, turned back the bedclothes, lifted her in his arms, strolled with purposeful determination out through the French windows, across the lawn, moved over to the banks of the Yarra that were beautiful at that point, and laid her down gently on the green sward. And meanwhile she was, of course, completely dumbfounded with fear and terror; only when he had laid her down was she able to marshal a few words. She then said with bated breath-and this is the dramatic moment which Professor Wright's whole address brought back to me-she stammered and said "A-a-and what are you going to do now?" And the dark handsome stranger looked straight at her as he spoke his first words. And he said "Lady, it's your dream!"

I therefore must address myself to a much narrower topic within the limits of time that I have. This is the question, What sense are we to make in terms of human 
survival of the main positions in the controversy concerning the U-2? And I would like you, if you would, to approach this with me by the light of reason as applied to our whole present situation, and not just in terms of the diplomatic and propaganda situation that arose after the U-2 incident, partly resulting from certain difficulties and ineptitudes of the United States administration in dealing with it. I would like us rather to address our minds to the import of aerial espionage, and also along with this of espionage from outer space; to that import for the common interest of both sides in the present power struggle. I want to put before you a view of espionage which transcends that of traditional international law. Not that international law leaves no room for this view; on the contrary it leaves plenty of room for it. But the traditional law has never addressed itself to this aspect, because the two-scorpions-in-a-bottle situation of our day produces a context for the operation of espionage in the common interest of both sides which has never existed before.

This is what I want us to concentrate on, to see if we can detect, in default of the achievement of an international system of inspection, some possibility of what I might call reciprocally tolerated espionage. This would be only second best, of course, to the assurances against surprise attack which could be provided by an agreement for international inspection, the matter on which, I understand, my friend Roland Stanger is going to speak shortly.

Now on the basis of the facts finally admitted by the United States, ladies and gentlemen, the charge that 
the United States violated international law in the U-2 incident must rest, it seems to me, on one or other, or both, of two grounds. It is rather important, however, to distinguish these grounds from each other. One is the ground of territorial intrusion-flight over the air space of the Soviet Union; the other is the ground of espionage, and of course a main drive of Professor Wright's paper has been that espionage as such is illegal in peacetime. Now, I don't want to make any question, nor did the United States Government, that there was a violation of international law in the U-2 case in respect of the territorial intrusion. There is no debate about this. What is debatable is why, in view of the fact that territorial intrusions by one state on the territory of another state are not uncommon, and give rise usually only to a minor commotion, this particular intrusion gave rise to so great a crisis, and why even friends of this country, and some of its own leaders of thought like my fellow guest here today, have taken such a grave view of the action of the American government. The mere naughtiness of a territorial intrusion does not explain all this.

The second possible ground then is that which Professor Wright seems to pinpoint for you today, namely, the ground that espionage as such in peacetime is illegal in international law. This is how I have understood Professor Wright's article in the American Journal of International Law on the U-2 incident. ${ }^{1}$ And this is how I understood him this afternoon. Perhaps if I am misunderstanding him, he will correct me. But I do wish to say that if he is separating out peacetime espionage as 
itself an international delinquency of the state permitting it, even if there is no illegal territorial intrusion, then I must register an almost complete dissent from his view. I find no support for such a view except perhaps some dicta in ex parte Quirin, ${ }^{2}$ and in the Dutch case, re Flesche; ${ }^{3}$ and these are far from decisive of so important a question. I find no support for it in the practice of states. For example I find no attempts of aggrieved states, after the spying state has disowned its spy, to shift home responsibility for the espionage to the spying state; yet surely if espionage were a state delinquency in itself the aggrieved state would not always have been content to take such disclaimers at their face value.

I throw in as seeming to me to contradict such a view that, according to the principle stated in the Lotus Case, ${ }^{4}$ it is for those who assert the existence of a rule of law restricting state activity to show that such a restrictive rule exists. And in any case it is not a self-evidently sound approach to the newish problems of peacetime espionage to assume that it must be unlawful unless it can be justified on some specific grounds. In face of a situation of such rapid technological, strategic, and psychological change it seems to me to be particularly important rather to approach the matter by asking whether there are any principles, manifest in the praetice of states, which evidence any existing restrictive rules, or any sufficiently close analogies. With the greatest respect, I can at present find none. There are, of course, a lot of cases to which Professor Wright refers concerning territorial intrusions, concerning the exer- 
cise by one state's officers of governmental functions on the territory of another state, like liberating prisoners from jails, or cases of diplomats abusing their privileges and immunities by engaging in espionage. In such cases, however, the delinquency arises, in my submission, not from the espionage but from the collateral illegality.

Nor, ladies and gentlemen, is this a mere quibble between lawyers. For in the future which is before us the cases of espionage where there is no collateral illegality are the very cases likely to be most vital for the future of mankind. Because, with satellites like Midas, and other technical developments, we are approaching a situation in which the military reconnaissance function can be exercised from outer space or from the periphery of territorial waters, and there will be no collateral illegality involved in the major spying activities. At this point, the question that Professor Wright is either leaving ambiguous or is resolving too confidently against the legality of peacetime espionage as such (and on which I dissent) will become a very crucial one. It is whether, apart from collateral illegality - there being for example no territorial intrusion when you're in outer space-espionage is a delinquency of the state which engages in it. My respectful submission, Mr. Chairman, is that as the law now stands, there is no sufficient warrant for saying that international law does not permit state-authorized espionage in peacetime.

I am, of course, with Professor Wright in saying that clearly no such state delinquency is involved in wartime 
espionage. The main effect of such espionage is that it places the individual in a legally exposed position, as it were, without the protection of his own state, to the legal measures of the aggrieved state. Professor Wright recognizes that there is no state delinquency in wartime relations, and I am adding the footnote that I also believe that there is no state delinquency in peacetime relations, if no collateral illegality such as intrusion on territory is involved. If, as I think, there is here an absence of any prohibitive rule, what is left for us to consider (and no doubt we ought to consider it) is whether there should be a rule prohibiting such peacetime espionage.

This is a question of how the law should be changed or developed. And before we begin or even try to answer this kind of question we must bring to reacknowledgment (for you all know these things of which I am now going to speak) some of the elements of the dynamic change in which the law of espionage, such as it is, now has to operate. We may thus bring into the matrix, or backdrop, of this branch of the law, realities which have never before been operative upon it, and which may therefore radically influence our outlook on the part of the law of espionage which still has to be worked out.

There have been, for example, within the time of even the youngest damsel among you, most drastic changes of a psychological nature affecting the centers of international decision-making, whether in Moscow, in Washington, or in other capitals. The most drastic of these is that there is a common interest in all 
of them in avoiding the use of nuclear weapons; and this psychological fact goes into every decision that has to be made. Now the conclusion is sometimes drawn from this that, since the peril of using these weapons is so great to everybody, they will never be used, so that war is already a thing of the past. This is a dangerous half-truth. The only truth in it is that this has become a psychological factor in all decision-making.

Along with this important psychological change, and also operating constantly, is the widening and dispersal of the directions of state concern with espionage at both the active and passive ends. And along with this come changes in men's attitudes towards the territorial domain of states which are now in full flow. Anyone who is familiar with the vast and growing literature on outer space, on the problems of reconnaissance from outer space, the problem of the subjacent state and the satellite or outer-space vehicle, quite apart from the fact that foreign civil aircraft constantly fly over the territory of most states-anyone aware of these things must also know that territorial sovereignty in the old sense of full psychological sacrosanctity is no longer with us. There is in the background too, psychologically, what I have called elsewhere the depersonalization of weapons and the processes of killing, reinforced by ideological propaganda.

On the technological side, any projection of the law of espionage must surely have in mind the revolution in human communication that we are facing today. Espionage and its law grew up when communication was mostly face to face, or by physical writing, by carriage, 
on foot, or on horseback. Obviously, we must do a great deal more thinking in an age which can achieve instantaneous radio communication by the use of tiny, secretly disposed instruments; which can transfer sound and images by bouncing waves off the ionosphere; and which can produce satellites capable of photographing from great and immunity-giving heights, and craft capable of probing laterally from outside territorial waters. Such developments would, in any case, prevent us any longer from arguing mechanically from the traditional rules about maritime espionage to the conditions of modern conflict. But at the very same time, the espionage situation itself, if I may so speak of it, is being transformed. The kinds of information that we are accustomed to think that spies seek are changed by the nature of modern warfare, just as the kinds of contraband have changed that states want to seize in wartime.

Let me remind you, so that we are warned about getting too far behind the times, that as recently as 1909 the leading thinkers of the major naval powers were sufficiently ill-advised to declare that certain kinds of commodities could never be of warlike use, and therefore could never be contraband. As late as 1909, they included, bless my soul, industrial diamonds, rubber, silk, and (I add in parenthesis) perhaps appropriately, nuts! These are commodities which in 1909 couldn't conceivably (they said) be useful for war. And I am reminded, too, of the Law Officers of the British Crown back in 1854 who were asked to advise whether a British citizen, who was professor of science at the Mos- 
cow University while Britain was at war with Russia, might be guilty of treasonous activities. The learned Law Officers used these delightful words: that of course if he continued in the military, naval, or political service of Russia this would be treasonous. But (they said) professors, including professors of science, were different. Even by working at a Russian University such professors would not be guilty of any disloyalty; for, said the Officers loftily, "civilized nations do not make war against literature or science, nor do they desire to prevent the progress of science even in the country of an enemy." ${ }^{5}$ We must, I venture to think, avoid this kind of anachronism. For our very survival now depends on being contemporaneous in our thinking, and not pretending that we can either govern or preserve ourselves in a transformed world, by the use of notions no longer applicable.

This point also bears on the question of the effect of disclaimer of a spy by the sending state. Professor Wright has mentioned this as being the gravamen of much criticism of the United States government. I may say I am not always in the position of supporting a position of the United States government, or of any other government. I try always to keep a certain scholarly independence. Yet I think that, in the case of the U-2 incident, the United States government has had a raw deal, even from some prominent thinkers. Clearly, when the secret agent's equipment consisted of oral instructions, some invisible ink, a memorized code word, and a couple of memorized addresses, together with a phial of poison in his breast pocket for emergencies, 
this is one espionage situation, isn't it, ladies and gentlemen? And in this kind of situation, it is true that governments have regularly disowned their spies and they have been able to do so without looking too silly. Why did they disclaim? Professor Wright seems to assume that it was because peacetime espionage was a state delinquency; and Professor Wright is then at a loss to understand when Oppenheim speaks of espionage in peacetime as lawful in the same breath as he observes on the regular state disclaimer of the spy. The fact is that Oppenheim does treat peacetime espionage as lawful; and I follow him in this. When Oppenheim says ${ }^{6}$ that the sending state "cannot" acknowledge its spy, he was uttering a psychological "cannot," not (as Professor Wright assumed) a legal "cannot." The psychological point, as I see it, is that the espionage situation is, ladies and gentlemen, like some situations that occasionally arise between friends and even, I understand, between husband and wife, when one of them does the sort of thing about which it isn't really any use for them to talk. The disowner of the spy is (as it were) a way of forestalling the discomfort of negotiations which could in any case only be fruitless; the practice of disowner, therefore, may have no particular significance at all in determining what the law is.

Contrarily, I have already put it to you that if peacetime espionage as such really did involve state delinquency, it would be a most surprising thing that aggrieved states, when there was such a delinquency, should apparently have allowed the sending state to acquire immunity from its consequences merely by 
making a disowner. It is not the general habit of aggrieved states to take the mere ipse dixit, the bare word, of the culprit state that it hasn't been naughty really.

But I must not linger further on this. I want to come to my concluding point, which is really a main point. Professor Wright dealt with the various alibis or defenses put forward by the United States Government, and I don't want to go into their merits. It seems to me that Washington's reply, or the gist of Washington's reply, was, on the face of it, a very strange one. It was necessary, as the President said, to get information from behind the Iron Curtain for lessening the danger of surprise attack against the democratic world; and "no one wants another Pearl Harbor." And Mr. Gromyko made the expected assault on this, making it look very ridiculous by saying, in effect-If each state is entitled to judge whether its fear justifies particular measures, wouldn't there be a commotion in the United States if Soviet spy-craft suddenly appeared over Chicago? Well, Mr. Gromyko had to be reminded (as indeed he was by the American representative) that there would not necessarily have been much of a commotion, because the very start of all this business was a proposal by President Eisenhower which could have permitted Soviet spy-flights over Chicago. In other words, when you penetrate a little below the face value of these arguments, you come to the thesis that I will now tentatively formulate, and which I'm sorry Washington didn't formulate for itself. Nevertheless it's worth our attention. If you do not have a system of international 
inspection and if you can't get one (and I think it is quite likely that we can't) then the function which international inspection is supposed to serve still needs fulfilling. You may not be able to fulfill it to the optimum extent by reciprocally tolerated espionage, but you may be able to reduce the dangers. It is not certain that you can, but the possibility surely is worth exploring.

The difficulty in seeing this arises from being hidebound by history. Espionage, historically, before this present age in which all of us are placed in peril by the nuclear balance of terror, has always been a unilateral, selfish, self-regarding, divisive activity used by one state against another to impose its ends on that other. And in this sense it is linked, as Quincy Wright insisted, with self-regarding intervention. But we are now in an age in which both sides have a common interest in neither being able to make a surprise attack. This is why the problem of an international inspection system is very largely a problem of building into some international system an adversary system of espionage for each side. And I feel confident (though I have not discussed it with him) that my successor on this rostrum will tell you that one basic difficulty (among many others) in the inspection problem is that of giving each side the confidence that the system contains a component of built-in espionage that is reliable from its own point of view. So that, while we think about international inspection (and the word "international" has a halo around it and makes us feel good), we had better remember that a good system of international inspection 
must be basically a system of reciprocal espionage, with a seal of international umpireship on it.

Suppose we cannot get this, ladies and gentlemen. Must we then just give up thinking about the job of mitigating for both sides the dangers of nuclear attack? Isn't this function still a function we must try to perform, by whatever methods are available? And was not basically the position of your government, if you only probe it, and give it perhaps a teeny, weeny, little bit of reinterpretation, the standpoint which I am suggesting to you? Is not the rational basis of your government's position this: that a second-best solution, at any rate one worth considering, would be for the two sides to reciprocally tolerate espionage. It is only up to this point that I can take you in the time available, except to try and give you a foreshortened glimpse of two consequential problems.

One is this. If we recognize that some part of espionage activity in our existing world represents not the divisive interest of each side against the other, but the common interest of both, then it becomes crucial to recognize that espionage may have either to be frowned upon, or to be approved according to the circumstances. Spying may serve the common-interest function (which I might call "the red-light function") of warning the spying state of the other's preparations for surprise attack. Or it may serve the divisive and destructive function (which I may call the "green-light function") for which it may still also be used in our time, namely, that of letting the spying side know that the other side is momentarily exposed to surprise attack, because of 
the level or disposition of its retaliatory forces or other defensive arrangement. And this equally applies to espionage by aircraft or by orbital or space-craft, or by amphibious craft like the X-15.

So that if we accept my main thought as something worth pondering, we are still only at the beginning of our problems. We still have to come to the question of how each side can be sure, in a system of reciprocally tolerated espionage, that the craft of the other are going to perform only the salutory red-light function, and not the dangerous green-light function.

And even if we think, as some do, that on principle we can distinguish these two aspects of inspection (and therefore in my theory these two aspects of espionage also), we still have very great difficulties. How is each side going to police the activity of the other to make sure that craft, which should be performing the redlight function, are not in fact performing the greenlight function? On this point, after much prodding of my brains, I have only a number of speculative ideasinto which happily I have no time to go.

1. Wright, Legal Aspects of the U-2 Incident, 54 AM. J. INT'L L. 836 ff. (Oct. 1960).

2. 317 U.S. 1 (1942).

3. Nederdanse Jurisprudentia (Netherlands), No. 548 (Special Court of Cassation, 1949).

4. Case of the S.S. "Lotus," P.C.I.J., ser. A, No. 10, p. 74 (1927), 2 World Court Reports 71 (Hudson ed. 1935).

5. 3 International Law Opinions 34 (McNair ed. 1956).

6. 1 Oppenheim, International Law, $\$ 455$ ( $3 \mathrm{~d}$ ed.). 



\title{
Space Espionage and World Order:
}

\section{$A$ Consideration of the}

\section{Samos-Midas Program}

\author{
RichaRd A. FALK*
}

Hon. Victor Anfuso, Member of the House of Representatives, N. Y.: "Mr. Khrushchev made a very fantastic remark that he saw no angels in the heavens. space?"

"Do you see any challenge to God in this venture into outer

Dr. T. Kieth Glennan, National Aeronautics and Space Administration: "No sir."

-Missile Development and Space Sciences, 86th Cong., 1st Session, House Committee on Science and Astronautics.

HE EFFORT of the United States to improve its knowledge of Soviet military installations is well known. It has taken a variety of forms: the release of cameracarrying balloons, the "open skies" proposal, U-2 overflights, and more recently (if Soviet charges are to be accepted), ${ }^{1}$ reconnaissance observation by subma-

- Associate Professor of International Law, Woodrow Wilson School of Public and International Affairs, and Research Associate, Center of International Studies, Princeton University. 
rines operating within Soviet territorial waters. None of these methods met (evidently) with enduring success. Hopes are high, however, that the Samos and Midas satellite program will, at last, do the job.

The plan is to launch several Samos satellites in polar orbit from Port Arguello, California, sometime before the end of 1962. The polar orbit assures passage over a large portion of Soviet territory. ${ }^{2}$ The Samos will carry photographic and TV equipment that permits perception of surface objects equivalent to what the human eye sees from one hundred feet. This should be enough to pick up troop concentrations, airfields, missile sites, and much other useful information. In addition to the work of detection, the Samos will perform a continuing surveillance role, since it can discern and report on military buildups taking place on the ground.

The Midas satellite plays supplementary roles. Available information indicates that Midas is designed to facilitate the use of outer space for global communication systems and to detect and report on rocket launchings. On October 21, 1961, at Port Arguello, California, the Air Force launched in polar orbit a Midas IV satellite (Project West Ford) to distribute, on a test basis, millions of copper wires in a widening band that will cover the entire globe; the wires will slowly descend towards earth until they reach the atmosphere, where they are expected to burn up. ${ }^{3}$ Scientists throughout the world, including Americans, have protested against Project West Ford on the ground of its interference with astronomical uses of outer space. ${ }^{4}$ Midas IV illustrates the interdependence of various uses of outer 
space, and the bearing of the claim of one state upon the preferred uses of other states.

Although Midas IV has military sponsorship, its exact military role is not clear. The main objective of the Midas program, however, is to put into outer space satellites that carry instruments capable of registering rays emitted by gases that accompany rocket launchings. Thus Midas will watch over the rocket-launching sites that Samos finds. In time, Midas will carry instruments so sensitive that they will be able to inform the United States of the number of missiles fired and their general direction, as well as their approximate point of origin. This will, it has been suggested, aid American experts to evaluate the progress of Soviet rocket activities with far greater precision than is at present possible. ${ }^{5}$ The Discoverer satellite, designed to utilize containers capable of bringing the photographs back to earth, is also relevant to this program of space observation. And a Soviet commentator has suggested that the supposedly civilian Tiros satellite used to photograph cloud cover in the service of meteorological study has also photographed Soviet and Chinese territory on behalf of United States military intelligence agencies. ${ }^{6}$

The satellite program, then, seems to offer the United States a valuable intelligence payoff that it has not been able to secure by other means. Our intelligence efforts have evidently had difficulty penetrating the heavy veils of secrecy that hang over Soviet military activity. In contrast, the competitive struggle for legislative appropriations in the United States leads to public dissemination of military information, including missile 
sites. Furthermore, Soviet intelligence operating by "conventional" methods seems to be more successful in the United States than ours is in Russia-although this is highly speculative. In any event, it is a view commonly held in the United States that "the intelligence gap" in favor of the Soviet Union is one of the serious threats to the survival of the West. ${ }^{7}$ The particular quality of Samos-Midas intelligence emphasizes its relation to national security. For the advance warning of surprise attack given by Midas, or at least the expectation of such advance warning, would increase the destructive power of the second strike and, so the reasoning goes, dissuade further an enemy from launching a surprise attack.

Of course, the Soviets purport to see things differently. They view Samos-Midas as an intelligence effort that helps the United States to plan a successful surprise attack. Why else are we seeking to observe missile sites? A second-strike, defensive use of nuclear missiles would choose cities and industrial centers as its probable targets. Only a surprise attack selects missilelaunching sites as its target, the goal being to eliminate the enemy's retaliatory capability. If the second-strike capacity is minimal, retaliation becomes a futile gesture; surrender seems preferable, and the surprise attack is fully successful. In any event, the force of the second strike is cut down.

The strategic importance of observational intelligence to the cold war makes this subject matter an intractable area for isolated negotiation. We have seen increasingly that neither the Soviet Union nor the 
United States is likely to forego strategic advantages in the cold war in order to promote the cause of world order. One need only refer to the 1961 Soviet resumption of nuclear testing or the 1956 Hungarian intervention and to the initiation in 1946 of nuclear testing by the United States on the high seas and to its participation in the armed invasion of Cuba in April, 1961, to sense the tendency of cold-war pressure to overcome considerations favoring restraint. Seen in this light, the prospects are indeed slim for depoliticizing a controversy over the legitimacy of ground observation from outer space.

One can summarize the extra-legal conditioning of the Samos-Midas program, then, by pointing to the opposed military strategies and contradictory interpretations of motive on the part of the cold-war rivals. The U.S.S.R. regards reconnaissance from outer space as a threat to its survival, because it takes the purpose to be the locating of targets for a thermonuclear surprise attack and the immediate effect to be the impairing of a tradition (with Czarist credentials) of secrecy about military affairs. The United States, in contrast, links its survival to an adequate warning system that will stabilize deterrence and discourage surprise attack.

How is such a conflict to be resolved? Is it a discretionary right of the United States to orbit reconnaissance satellites over the Soviet Union? And is it a discretionary right of the Soviet Union to shoot them down if it can? Have we no way, other than by force, to vindicate or refute such a claim on the frontier of technological development in outer space? How do we 
attain limits for national conduct in an area where there are neither authoritative practice nor converging interests to support an agreement? This essay can not give answers to these questions. It tries, instead, to describe the wider importance of the Samos-Midas program for world order. And it suggests a technique of evaluation that enlarges the horizon of relevance beyond the confines of military strategy. ${ }^{8}$ This approach aims at the development of a model of analysis for the role of law in the cold war; it is admittedly preliminary.

How shall we characterize the activity of the SamosMidas satellite program? Is it "espionage"? Does it make any difference whether it is or not? Traditional definitions of espionage ${ }^{9}$ emphasize its clandestine character, and one can argue that the "openness" of Samos-Midas activity puts it outside the scope of espionage. This argument might present Samos-Midas as a unilateral attempt to do what the open skies proposal sought on a bilateral basis. Such an interpretation would be more persuasive if it were coupled with a proposal for the internationalization of the activity under United Nations control. ${ }^{10}$ Observation from outer space, in that case, would become assimilated into the special needs for peace maintenance in a nuclear age. This approach deserves special consideration and supports a careful differentiation between the potential ${ }^{11}$ role of Samos-Midas activity and the egoistic, secret use of traditional espionage.

Such an interpretative problem parallels the Soviet claim that outer space should be available only for 
non-military uses (except in the event of war), and that Samos-Midas is a military use-related to the military effort, financed and administered by the United States armed forces. As such, it is an abuse of outer space, since it transforms it into a theater of military operations. ${ }^{12}$ The claim to use outer space for peacetime military purposes sets a very dangerous precedent. We must keep in mind the strength of reciprocity and estoppel in an area of behavior without clear legal norms. A use by $A$ warrants an equivalent ${ }^{13}$ use by $B$ and precludes objection by A. Thus A's use establishes a permissive norm. This basic pattern of international lawmaking should encourage sober reflection in advance of unilateral claims asserted at the frontiers of military technique. For instance, looking back on nuclear testing, one wonders if the United States would not have helped its cause on every level by pressing for a test ban or limitation in advance rather than by following a unilateral pattern of claim, subsequent estoppel and eventual anxious dismay.

Samos-Midas gathers and transmits its information without entering the target state. ${ }^{14}$ This means that there is no interference with the administration of the national society. The effort to recruit and catch spies is itself one of the objectionable aspects of espionage activities. Observation from outer space by unmanned satellites does not inject an information-gathering foreign agent into the lifeblood of the social order. A leading commentator suggests the analogy between SamosMidas and the permissible photographic observation of shore objects from aircraft overflying the high seas. ${ }^{15}$ 
However, this legitimation is qualified by the general duty to use the high seas in a manner that does not infringe upon the rights of the shore state, and further by the evident right of the observed state to view such observation as "aggressive" or "military" and take appropriate protective measures. ${ }^{16}$ This description of "the law" informs us only about the rhetorical techniques used by participants in a decentralized legal order faced with a conflict between claim (Samos-Midas) and objection (Soviet retaliation). As will be shown, the international legal order possesses techniques for a decentralized appraisal of legitimacy that applies to the Samos-Midas controversy. The factor of non-interference appears to support an evaluation in favor of the activity.

It has been universally conceded that a nation can forbid others to photograph strategic objects and events taking place within its territory. All nations, including the United States and the Soviet Union, strictly regulate and punish activity on the ground which seeks to obtain the same kind of information that Samos and Midas collect from outer space. The Chicago Convention on International Civil Aviation, uncontested national legislation, and the U-2 incident convincingly extend this power of prohibition to unauthorized information-gathering conducted in territorial airspace. ${ }^{17} \mathrm{It}$ seems generally agreed that unauthorized observation and photographing falls within the developing concept of "espionage." In fact, even our newspapers have dubbed Samos-Midas "space spies," "spy in the sky," and the like. State practice and general usage both 
argue for the treatment of unauthorized aerial observation as "espionage," subject to regulation by the victim state. $^{18}$

It is, of course, possible to stress the extra-territorial character of Samos-Midas activity. One emphasizes the territorial limits of national sovereignty and the nonterritorial status of outer space. But for the state that is the target of observation it matters little where the observer locates himself. The functional quality of espionage from outer space is, from the viewpoint of information yield at least, no different from espionage in airspace. Professor Katzenbach has perhaps overstated this point when he suggests that the height of the activity is of no relevance to a proper determination of its validity. ${ }^{19}$ Clearly the trend is toward the replacement of mechanical criteria by contextual judgments as the basis for the proper delimitation of jurisdictional competence. Rather than rely on the physical locus of constituent acts, or on some other isolated qualifying element of the facts-for instance, the nationality of the actor-it is now thought better to make a comprehensive appraisal of the reasonableness of the particular claim by reference to all affected interests. ${ }^{20} \mathrm{~A}$ jurisdictional decision, then, depends upon a balancing of the competing interests of claimant and protesting states. The jurisdictional model of decision-making is taken primarily from the practice of national courts, but it is applicable here as well, since executive officials of the United States are called upon to decide whether to make a unilateral claim. The process of rational decision, as McDougal has shown so well, is structurally 
similar, regardless of where the decision-maker is located in the social process. ${ }^{21}$

On the basis of a consideration of the Samos-Midas plan it seems, as I have said, prudent to characterize it as "espionage." This puts it easily within the legislative reach of Soviet law. For it is legitimate to prosecute for espionage even if the defendant acts in foreign territory. The reach of United States economic regulation serves to illustrate this kind of a claim in a situation in which the prosecuting state has a lesser interest; ${ }^{22}$ that is, the extension of claims to protect national security has priority over the extension of claims to defend the economy. If a state can regulate espionage taking place in another sovereign state, then certainly it can impose equivalent regulation upon similar activity in outer space. Giving the activity a status of "espionage" makes the locus of conduct irrelevant to the legislative claim. It seems clear, then, that the Soviet Union has legislative competence to characterize Samos-Midas as "espionage" and to prescribe appropriate remedies. One of the most characteristic features of the international legal order is the wide discretion given to a nation to characterize activity for purposes of applying its legal policy. The Nottebohm case illustrates the attempt of a supranational tribunal to discover limits to this power of a nation to characterize in the area of nationality. The case is enormously significant as a challenge to the tradition of decentralization. The extension of Nottebohm thinking reflects itself in the "genuine link" requirement for merchant shipping that has found its way into the Geneva Convention on the Law of the 
High Seas as a rebuff to "flags of convenience." ${ }^{23}$ Without vertical institutional development, however, it remains to be seen whether international order loses or gains by attempts to centralize and objectify the power to characterize. We give up the simple criterion of national discretion, and yet provide no substitute means to specify legal status. Is this not, then, a premature attempt to verticalize international legal order? Despite Nottebohm it seems accurate to affirm the capacity of nations to characterize activity that is threatening to their military security. ${ }^{24}$ In this respect we take note of the United States claim of Air Defense Identification Zones as a parallel instance.

But in the case of Samos-Midas-and this is the novelty of the situation-the United States supports its claim by reference to its military security. That is, we claim that the surveillance of the Soviet Union by our satellites is an essential precaution against surprise attack. The claim, in effect, makes espionage from outer space a matter of self-defense. Thus, in a formal sense, two irreconcilable claims are present. In a centralized system this would call for the intervention of judicial or legislative action to resolve the competing claims by compromise or choice. ${ }^{25}$ But what is to be done in a relatively decentralized legal order?

The probable course of conduct in a decentralized legal order will emphasize the maximum assertion of the opposed national claims at each stage of the controversy. Thus the United States will try to orbit the satellites and the Soviet Union will try to shoot them down. However, a preferred course of conduct would 
look also to the reasonableness of the assertion of the claim, given competing interests, and make every effort to justify it to the target state. This applies to the United States decision to orbit more than to the derivative Soviet decision to interfere with the satellites. For the nation that disturbs the status quo in a decentralized legal order bears the main burden for the instability that follows. The position of the United States, as the leader of the bloc resisting the expansion of the revolutionary nations, ${ }^{26}$ entails a special national interest in strengthening international order. Therefore it is with dismay that one observes our government's progressive neglect to consider the bearing of international order upon national welfare. It is not that we must sacrifice national security to promote world order, but rather that we should see whether the sacrifice in order is worth the gain in security. The U-2 incident, the sponsorship of the Cuban invasion of April 1961, the Connally Reservation, and the fight to keep Formosa on the Security Council are instances in which an overly narrow interpretation of national interest unnecessarily impairs the quality of contemporary world order. Likewise there is no evidence that the decision to put the Samos-Midas program into operation takes adequate account of its probable destabilizing effect on other activity in outer space. So far, outer space has been used compatibly by cold-war rivals for peaceful purposes. ${ }^{27}$ It seems hazardous to make outer space a part of the cold-war arena. It is difficult, without access to intelligence appraisals, to suggest the probable net gain or loss from Samos-Midas. Nevertheless, it is possible to 
urge a basis of decision that considers the consequences for world order as well as the gains for military intelligence.

It is probably not useful to debate "the legality" of espionage in the traditional system of international law. For espionage, as such, possesses the peculiar quality of being tolerated, but illegal. ${ }^{28}$ This odd status, which is much like that of prostitution in many European countries, has encouraged a practice whereby states engage in espionage but do not come forward to defend an agent who is caught by the techniques of counterespionage. Consider, for example, the silence of Soviet authorities during the long trial of Colonel Abel, as well as the recent Soviet willingness to exchange Powers and Prior for Abel. The silence of the state sending the espionage agent usually results in the target state's directing its sanctions only against the detected agent. The employing state is not drawn formally into the espionage trial, nor is there any effort to impose legal responsibility upon the state for the espionage it has commissioned.

However, the rules of the game must be observed. If the espionage activity involves an independent violation of the target state's sovereignty, then the sending state makes itself vulnerable to direct charges of illegality. Likewise, if the sending state steps forward to acknowledge and defend its espionage ventures, it would also seem to assume responsibility for the illegal activity. It was such an acknowledgment which created some of the unusual problems raised by the U-2 incident. 
Let us consider now the Samos-Midas program from this perspective. First of all, the program would seem to constitute "espionage" under explicit government auspices. Part of its legal quality would depend upon American motivation, and especially on the extent to which the information so gained contributes to defensive rather than aggressive policies of national defense. That is, the test for the relative illegality of espionage rests to some degree upon one's judgment of the end being sought. However, in view of the usefulness of Samos-Midas for aggressive purposes, primary responsibility would appear to devolve upon the United States. The project is an attempt to undermine the security regulations of a sovereign state during peacetime and, as such, would seem to violate the independence of the target state. A strong argument on behalf of Soviet objections could be made before an impartial decisionmaker. The United Nations Security Council would be an appropriate forum for discussion and appraisal. Characteristically, as we have said, the government sponsoring "espionage" is not explicitly connected with its agents, and the enforcement state proceeds against the agent as an ordinary criminal defendant; but Samos-Midas presents a novel pattern of espionage activity that renders much of the legal reasoning applicable to traditional espionage obsolete.

Presumably the satellites, as governmental property devoted to a public use, would, by application of normal principles, be entitled to sovereign immunity. However, the use of satellites to break the laws of target states would, at least after warning, allow the latter to 
take coercive action in self-protection. Furthermore, immunity is primarily a judicial inhibition. In any event, it is unlikely that the disposition of the controversy would stress to any degree the sovereign ownership of the satellites.

Finally, there is the Soviet claim to engage in extraterritorial enforcement. Even if one grants that outer space is "outside" of national territory, it is still quite legitimate to reason, by analogy to the practice in contiguous zones on the high seas, that a state may make claims that are reasonably necessary for its national security. Thus there would be no need to claim sovereignty up to the heavens in order to justify Soviet enforcement of its espionage laws in outer space. Russia could quite reasonably assert a particularized claim to control espionage, even if the objectionable acts were all performed in outer space. Putting this into jurisdictional rhetoric, we can say that a jurisdictional claim to assert control over a particular activity in outer space need not rest upon a prior establishment of national sovereignty over outer space. Neither the physical locus of conduct nor sovereignty are indispensable bases for valid jurisdictional claims, although both are frequently used. In fact, it is important to encourage the formulation of particularized claims, supported by their reasonable link to national interest, in preference to wholesale extensions of sovereignty that will validate, among other things, the particular claim. The experience with territorial waters is instructive. Latin American claims to wide (200-300 miles) belts of territorial waters were prompted by a desire to keep for- 
eign trawling fleets out of coastal fishing grounds. It would have served this interest, and kept a maximum area for free, unimpeded use of the high seas, had these nations instead put their claim in the kind of specific language used to justify national control beyond the territorial waters. ${ }^{29}$ The particular claim, justified by reference to national interests, meets the needs of world order far more than does the crude exclusivity of the notion of sovereignty. For wherever it is functionally advantageous to share use, it is best to work out a solution along specific lines. The dichotomy between freedom (of the high seas, of outer space) and sovereignty is an inept way to allocate legal competence in an area where most uses are inclusive, but where a few are exclusive. ${ }^{30}$ World order advances by accommodating these two sets of national interests; that is, by encouraging the awareness that national interests often profit more from foregoing exclusivity than from insisting on it. ${ }^{31}$ The growth of supranationalism in Europe, the Antarctic Treaty, and the success of the specialized agencies of the United Nations bear witness to an emerging realization that sovereignty is not the answer to the allocation of authority and resources in areas which are of genuine interest to more than one nation. But such promising developments as these depend upon the willingness of nations not to use the community form as a base for hostile operations against a member of the community. ${ }^{32}$ Here again one senses the potential harm that may be done by Samos-Midas. In the struggle to minimize exclusive claims in outer space it is dangerous to jeopardize the perceived safety of other nations. For 
to do so causes the minimum basis for trust to disappear and the functional compatibility of interests to vanish from perception.

This discussion raises a general theoretical issue relevant to the future course of international legal development. The facts of progressive interdependence, so frequently acknowledged in recent literature, lead to a need for sharper allocational concepts in the international legal system. When nations were relatively independent in the pursuit of their interests, it was desirable to stress the simplicity of the ideas of sovereign exclusivity and inclusive freedom. Interdependence requires more subtle categories of international law, categories which will give maximum support to as many genuine national interests as possible. The encouragement of ad hoc justifications for particular claims accords with this need. It allows the process of claim and resistance to claim to emphasize relative functional considerations rather than abstract categories of legal status. This seems to be the best way for an interdependent but decentralized legal order to proceed if it is to solicit maximum support from national actors. This is very important, because the slow growth of supranational legal order depends heavily on the development of trust on the national level. And trust emerges from the perception of a non-arbitrary attempt to serve the community and its members.

All this bears on the attempts to solve the problems of outer space by drawing a rough analogy to the status of airspace, the high seas, or the polar regions..$^{33}$ Thus, using the simplified traditional doctrine, one extends air- 
space upward forever and affirms a notion of sovereignty (although this is so patently impractical that it dissuades most), or one finds a boundary for airspace and proclaims the freedom of outer space, or one stresses the prescriptive character of acquired rights in outer space. The process of claim underneath the crude doctrinal categories provides considerable guidance from past experience, especially with regard to the historical administration of the high seas. Professor Lipson had made this point with admirable succinctness:

In maritime law and practice there is not merely a zone of territorial waters, a single contiguous zone, and the free high seas; there is a whole cluster of zones, overlapping and intersecting, established at different times for different purposes by different states (unilaterally, bilaterally, and multilaterally) with different degrees of formality, enforced by different methods, and accepted in different degrees by varying numbers of other states.

This general view is made quite concrete:

No unitary rule could or should be devised to cover this motley patchwork; there is no reason why one rule of law must apply to the regulation, control, prohibition, or mutual tolerance of such diverse activities as navigation, fishing, conservation of fisheries, and cable-laying; naval maneuvers and antisubmarine patrol; the use and conservation of resources on the sea bed; enforcement of customs regulation; and protection of neutrality. It is this very diversity of legal order, stemming from the diversity of policies and purposes, fitting the diversity of activities and conditions, that will pro- 
vide a fruitful analogy for what must be a gradual development of the law of outer space. (Emphasis supplied.) ${ }^{34}$

This sophisticated view of analogy, stressing concrete legal problems rather than overarching doctrinal abstractions, is the basis for rational law-planning in outer space. The facts of interdependence, highlighted by the problem of distinguishing between military and peaceful uses, make it essential that nations assert their claims with a clear sense of community welfare in mind. Allocations on the high seas could allow specific unilateral assertions based on a narrow view of national interest without often risking, until very recently, community welfare. Rational allocation of authority to act in outer space, however, requires a broader view of national interest that incorporates the genuine concerns of other nations if it is to foster the growth of a legal regime based upon maximum use and minimum friction. It is this emphasis that is urged here for an appraisal of the legality of the Samos-Midas program.

We can see that Samos-Midas seriously threatens the prospects for a co-operative development of outer space. The Soviet Union can reduce the threat somewhat by directing its objection at the use of outer space by the United States for military espionage rather than by resting its objection upon some claim of sovereignty over that portion of outer space that is "above" its territory. Similarly, the United States can defend its actions by asserting the reasonableness of SamosMidas in view of its non-interference with the Soviet 
social order and its contribution to the United States defense system; such a defense could be made dramatic by an offer to put Samos-Midas under supranational administration. Although there is no easy solution to this conflict of national interests, there are more and less responsible ways of seeking a resolution.

Is this argument changed by the fact that SamosMidas orbits through "outer space" as an unmanned instrument? Such an inquiry is independent of, although related to, the earlier discussion on jurisdiction. It looks upon the issue from the special perspective of national sovereignty and its distinctive ordering role in international affairs. ${ }^{35}$ Does a surface state have any sovereign control over activity that takes place in "outer space"? President Kennedy recently told the General Assembly of the United Nations that "the new horizons of outer space must not be riven by the old bitter concepts of imperialism and sovereignty." ${ }^{36}$ This presumably means that the development of outer space should not proceed by states claiming exclusive control over specified uses or regions of outer space. It looks toward some co-operative regime established and operated by legal institutions and techniques. However, "sovereignty" also refers to the capacity of states to generate legal order. But how can we overcome the contradictory national policies of cold-war rivals? With the objective of legal order in view, let us examine the ways in which disputes as to contested uses of outer space might be handled under the circumstances of present political conflict. Here, the role of national sovereignty - not as a way to validate claims to exclusive control 
but as an agent to establish the legitimacy of particular claims or to bring into being a legal regime-is indeed complex.

One steps into a dense jurisprudential jungle at this point. The delimitation of national sovereignty, as ordering agency, is among the most slippery subjects in international law. It is especially problematic in a case, such as this, where prior experience offers relatively little guidance. The legal order tends to resolve present controversies by reference back to past norms and dispositions. When the past does not provide guidance, and the issue is important, the legal order in a centralized social system tends to generate a new solution through the agency of legislative action. The international legal order lacks central legislative institutions. It depends, instead, upon decentralized ordering techniques to meet the challenge of a new situation. But the outer limit of innovation in a decentralized system is reached at the point where the interests of the powerful actors within the system begin to diverge significantly. For international law this means, among other things, that the equivalent of legislation-at least of a formal variety-must satisfy the dominant interests of powerful national actors. Thus it is difficult to anticipate a formal resolution of a dispute-not covered by the inherited system ${ }^{37}$-when antagonistic interests of the United States and the Soviet Union arise from coldwar subject matter. This analysis seems suggestive for our attempt to understand the bearing of international law upon the United States' plan to use outer space for "espionage" against the Soviet Union. Those who 
would resolve such a controversy by negotiating an agreement on the degree of national sovereignty over outer space overlook, it would seem, the relevance of the character of the international system to the prescription of new norms. The incapacity of the international system to provide orderly ways to test new claims is a serious cause of contemporary instability. A nation is given the choice of self-restraint or recourse to unilateral action backed by force. The danger of forcing such a choice back onto the national level is illustrated by Israel's initiation of the Suez campaign in 1956 and by the revolts of oppressed peoples in Africa. Samos-Midas also illustrates the inflexibility of the system. There is no institutionalized way to determine the validity of the United States claim, and the leaders of the two nuclear blocs must settle the issue by give and take. Once the satellites are put in orbit, a cycle of friction and retaliation is likely to begin. This raises, of course, the whole problem of the relation between international law and social change in the world today. The instability of the system results most significantly from the absence of supranational legislative techniques, the existence of oppressive national governing elites, and the willingness of cold-war rivals to intervene on behalf of contending internal factions. And rigidity is characteristically present whenever a new controversial claim has cold-war relevance, as does Samos-Midas.

Adjudication is formally possible. The issue could be put in justiciable form: Are observational satellites forbidden by international law? But the negative consid- 
erations applicable to legislation apply a fortiori to adjudication. In addition, the Soviet Union refuses to allow legal order to emerge from supranational decisions; it takes a very conservative view of transfers of sovereign discretion. Finally, the establishment of a legal regime for outer space is a polycentric issue ill suited for adjudicative techniques and institutions. ${ }^{38}$ The indefiniteness of the grounds of any possible decision tends to undermine its acceptability to the losing litigant. Nations generally refuse to submit important legal controversies to adjudicative organs when they can not, in advance, envision the general character of the legal solution. In any event, the status of SamosMidas implies a determination of an entire legal regime for outer space. This assumes a scope of inquiry and decision that is not normally possible in the judicial process.

An alternative to a formal decision in advance is to accept the effectiveness of the claim to orbit the satellites as a criterion of legitimacy. Thus the United States is not forbidden to put Samos-Midas in orbit, but neither is the Soviet Union forbidden to shoot the satellites down. The Harvard Law Review put it this way in a perceptive note:

.. . Whether the Soviet Union will choose to destroy American spy satellites when it becomes capable of doing so depends on Soviet national goals as conceived by the Soviet leaders. For the purpose of a legal analysis, however, it is sufficient to observe that whatever the Soviet Union does in this regard will not appear to be violative of international law. . . . (Emphasis supplied.) ${ }^{39}$ 
Reliance upon effective control as a determinant of the legitimacy of "military" claims is an undesirable way to fill a legislative vacuum. It tends to accentuate the formative role of relative power in international affairs. Small nations, lacking space technology, are then left without protection. This promotes further the bipolarization of outer space, as only the United States and the Soviet Union possess the technological base for extensive space activity in the period ahead. It also makes coercive conflict an institutional technique for accommodation; this may be a last resort, but it is hardly acceptable if alternatives can be found. The habit of testing limits by awaiting the application of counterforce adds to the instability of the times. It is not an implication of conflict on the political level.

A voluntaristic theory of international obligation, as formulated by the Lotus majority decision, gives a supporting analysis. ${ }^{40}$ The basic idea is that the objecting state has the burden of showing that the defendant state acted in violation of an existing rule of international law. Put affirmatively, this means that a state may do whatever it is not expressly forbidden to do by international law. Thus in areas where there is no consensus as to even the existence of a legal order, much less its quality, a state may do whatever it pleases, subject only to another state's right to act in self-defense. Specifically, the United States may launch its observational satellites and the Russians may shoot them down if they purport to do so in self-defense. ${ }^{41}$ The Lotus approach when coupled with the customary right of self-defense seems rather similar to the solution reached 
by the dynamics of effective control. The U-2 incident suggests that such approaches lead to serious intensifications of cold-war tensions and interfere with whatever prospects for wider accommodations exist at the time. ${ }^{42}$ In addition, one may question the legality and wisdom of authorizing defensive force to test "the permissibility" of the Samos-Midas satellites. The Charter renunciation of force is qualified by the limited grant of Article 51 that preserves "the inherent right of individual or collective self-defense if an armed attack occurs." Certainly the observational satellite does not constitute "an armed attack." It is true that some Charter experts contend that Article 51 preserves "the inherent right" which includes a decentralized determination of what must be done in self-defense. ${ }^{43}$ But such a broad interpretation of the right of self-defense is less plausible than its narrower alternative, and dissolves a fairly objective standard for the use of defensive force. The need for stable limits on the use of force in a world filled with nuclear weapons suggests the high seriousness of following a course of action that gives a victim state no real alternative to the use of defensive force. It is with this in mind that American policy-makers should consider carefully the advisability of presenting the Soviet Union with a situation in which its vital interests can be protected only by recourse to force. ${ }^{44}$

This essay seeks to deal with the contemplated Samos-Midas program in light of the struggle to achieve minimum stability in world affairs. Much of the discussion of this kind of issue loses sight of the national interest in world order by its focus upon the national in- 
terest in getting the upper hand at the moment in the cold war. The relation between these two levels of interest is indeed obscure. We improve our understanding, however, by growing aware of the distinction.

What is the relevance of the cold war to the quest for legitimacy in controversial areas of world affairs? Bipolarity, nuclear weapons, the cold war-each conditions the possibilities for legal growth. The SamosMidas program raises directly such issues of relevance, since it so obviously deals with the perceived vital interests of the bloc leaders in the cold war. How much is legitimacy worth to us in our dealings with the Russians? Should we ignore legal restraints so as to meet the communist challenge? We find the attitude of Admiral Ward at one end of the spectrum:

Isn't it about time to free ourselves of our deception that accommodations can buy peace from the Communists, and that peace with them can be secured through law-even space law? ${ }^{45}$

Law, then, becomes for the Untied States a matter of unilateral self-restraint, as there is no mutuality of commitment. The Soviets manipulate legal obligations to suit their political objectives, repudiating such obligations when their objectives change. The United States, in contrast, adheres to legal obligations once undertaken, and thus loses flexibility in the political struggle. In this view, legal restraint does not restrict Soviet freedom of action, but it does restrict ours. Therefore, we should stay clear of legal accommodations with the Russians on cold-war issues. Law acts as a 
trap. Presumably, then, the United States should go briskly forward with Samos-Midas regardless of its destabilizing consequences because Soviet ideology and practice make legal accommodation self-destructive. Law and survival act to contradict one another.

A more moderate attitude towards the role of law in the cold war gives critical emphasis to strategy and experience. Legal accommodation may be desirable, but only when we have enough experience to assess the bearing of a legal obligation upon our special needs for survival under present conditions. Loftus Becker, writing as Legal Adviser, said:

.. . Any sound body of law is based on a system of experience and known facts. There are a great deal of facts that we just don't know at the present time with respect to outer space and the conditions there existing. ${ }^{46}$

To this uncertainty arising from inexperience is added a deep distrust of the Soviet Union. Professor Lipson writes, for instance:

In this field [of outer space] as in other fields of international law, Soviet doctrine combines a pious attachment to the names of traditional concepts with a flexible, "instrumental" manipulation of the content of the concepts to serve the current needs of Soviet policy. ${ }^{47}$

Distrust leads to an insistence on very clear lines of commitment; hence, we must be sure what we are giving up before we agree with the Russians. In outer 
space we do not have enough experience, at present, to be sure that a commitment we make today might not place us in handcuffs tomorrow. Here again primacy is given to political factors, and survival is linked to freedom of choice rather than to stable limits upon choice. ${ }^{48}$ Law must be content with a marginal role, stabilizing areas of convergence after all the facts are in, rather than preparing an ordering scheme for the emerging facts. In the interim, the Lotus interpretation of sovereignty is used to justify all non-prohibited conduct. Existing law does not pertain to outer space. A state can thus do whatever it wants. Therefore, if Samos-Midas is helpful to us, we should proceed with it, since there is no applicable legal restraint. There is much to be said for an approach that is so simple and permissive; however, it fails to take account of the destabilizing effect of novel unilateral military claims in a decentralized social order in which the chief actors possess thermonuclear bombs. It also overlooks horizontal and provisional ordering possibilities that arise from unilateral self-restraint. These possibilities will not always gain more order (for example, the Soviet resumption of nuclear testing); but they may postpone friction and induce reciprocal self-restraint by the Soviet Union. We would have only the choice between surrender and preventive war if we did not posit a minimum Soviet commitment to world order and the avoidance of nuclear devastation. ${ }^{49}$ We often act, however, as if there were alternatives in the middle. Thus it is rational for us to take some risks to order international relations, even though it may conceivably give strategic 
benefits to the Soviet Union. Such considerations should influence decisions made with regard to the Samos-Midas program.

At the other end of the spectrum one finds a variety of scholars and concerned public officials who feel that it is essential that we establish a vertical legal regime prior to the assertion of various national claims. For instance, Senator Keating put it this way:

There will be no time for legal craftsmanship and judicial speculation after rival claims are made to the moon or to space itself. . . . The rule of law in the age of space is not a matter of philosophy, but a matter of survival..$^{50}$

And John Cobb Cooper has for years brought the weight of his learning and authority to bear in this direction. In 1960 he said at Leyden that "international peace and the future welfare of mankind demand that the Rule of Law shall be applicable with certainty to outer space." ${ }^{51}$ This requires a clear agreement as to the rights and duties of nations in outer space:

If the Rule of Law is to be applied in outer space, then I submit, as I have on other occasions, that the area of outer space must be determined, that its legal status be agreed upon, that the rights of States in the area be universally acknowledged and that the legal status of flight instrumentalities to be used in outer space be also fixed. ${ }^{52}$

This position stresses the ordering role of law, and does so without regard to the character of the international 
system as it now exists. Without techniques for social change, nations are unwilling to agree on a legal regime until they see clearly what is involved. Space and flight developments have proceeded with such rapidity that those proposing a basis for legal agreement have constantly had to revise their recommendations. Mr. Cooper's writings through the years provide a striking illustration of the need to change law to meet new technological developments. ${ }^{53}$ Agreement at any stage is inadequate at the next technological stage; renegotiation is always difficult since the new development has an unequal bearing upon the national interests of the participating states. This intractability would apply most vividly when extra-legal developments have an unequal effect on the military positions of the cold-war rivals. Vertical norms-that is, norms with formal status as supranational obligations ${ }^{54}$-could not withstand such a strain. It is probably premature, as Becker and Lipson suggest, to create vertical norms to govern outer space at this time. But it is never premature to seek horizontal legal order. The alternatives are too generally seen as comprehensive international agreement or chaos, vertical law or lawlessness, legal restraint or sovereign unrestraint.

My argument is that the effects of Samos-Midas upon the stability of the use of outer space as well as upon the use of defensive force challenge the rationality of the claims of the United States to use outer space for the military observation of the Soviet Union. Horizontal legal order particularizes the focus of inquiry upon the 
reasonableness of a national claim given all relevant considerations, including infringements upon the interests of other states. It is this process of inquiry, outlined in general form in this paper, that should govern the decision whether or not to put Samos-Midas satellites in orbit above Soviet territory. Final appraisal rests heavily upon access to data that are unavailable to the public: the importance of the information obtainable, the degree of Soviet objection, the probable success of Soviet attempts to shoot down or otherwise interfere with the satellites, the bearing the project would have upon possible co-operative space projects and the eventual demilitarization of space, and the development of alternative means to receive equivalent intelligence. Newspaper reports and legislative hearings reveal no consideration of the wider implications of the Samos-Midas program for world order. The strategic advantage of closing the intelligence gap seems to be taken as a self-sufficient justification for asserting the unilateral claim. Such a foreshortening of inquiry, which seems to exclude the bearing of Samos-Midas upon international order, is unforgivable in a world where potential enemies in a thermonuclear war boast of their "overkill" capacity. It may be part of the complexity of the times to acknowledge the importance of Henry Kissinger's remark that "the very intensity of our desire for peace may increase our peril." ${ }^{55}$ But such a perception should not lead us to deny the manifest rationality at the core of this intense desire. We must continue to apply our energies to the diminishing of 
our peril. At least as far as the Samos-Midas program is concerned, there is little evidence of such an application of energy.

Let us, then, be mindful of the bearing upon national interests of President Kennedy's recent plea to the United Nations: "As we extend the rule on earth, so must we also extend it to man's new domain-outer space." ${ }^{56}$ The character of the times makes this a national responsibility as well as a universal aspiration.

1. N.Y. Times, Aug. 29, 1961. For a military appraisal of aerial surveillance, see Ford, Tactical Reconnaissance, 12 AIR UNIVERSITY Q. Rev. 120 (Winter and Spring 1960-61).

2. Coates, Reconnaissance Satellites, 3 SpaceFLIGHT 100 (1961).

3. N.Y. Times, Oct. $22,1961$.

4. See criticisms by scientists from many countries, including the United States, N.Y. Times, Oct. 23, 1961.

5. "Two ballistic missile warning systems are currently programed. The first, already partially operational, is the Ballistic Missile Early Warning System (BMEws).... The second warning system, which will complement BMEws, is the missile defense alarm satellite (Midas)." Wheless, The Deterrent Offensive Force, 12 AIr Untversity Q. Rev. 59, 68 (Winter and Spring 1960-61).

6. See Zhukov, Space Espionage Plans and International Law, reprinted from INT'L AFF. 53-57 (Moscow, Oct. 1960 ), in symposium on Legal Problems of Space ExploRATTON prepared for Senate Committee on Astronautical and Space Sciences, Doc. No. 26, 87th Cong., 1st Sess. 1095, 1098 (1961) [hereinafter cited as Legal Problems]. (See same volume for representative formulations of Soviet bloc's views on the use of space.)

7. E.g., Hearings on Missiles, Space and Other Major Defense Matters before the Preparedness Investigating Subcommittee of the Committee on the Armed Forces of 
the U.S. Senate, 86th Cong., 2d Sess., 70 (1960); Baldwin, Intelligence and Survival, N.Y. Times, May 9, 1960. However, if the U-2 flights enabled the United States to plot geodetic co-ordinates within Soviet territory, the gap may actually be in our favor.

8. Crane, Planning for Space Legal Policy (paper presented to American Rocket Society, Oct. 1961), develops a similar position in explicating what he calls the "motivation for space policy"; for instance, he says that "the basic thesis of this paper is that law is gaining increasing value as an instrument to deny control of outer space to others, and that the potential advantage of a law-oriented space policy, should be integrated into military contingency planning." Contrast the approach taken in Aerospace Force in the Sixties, symposium in 12 AIR UNIVERSITY Q. REv. 1 (Winter and Spring 1960-61).

9. E.g., consider the definition given under Espionage in 5 EnCYC. Soc. Scr. 594 (1931): "Espionage is the practice of obtaining information about an actual or potential enemy clandestinely for possible use against the enemy."

10. Quigg, Open Skies and Open Space, Legal ProbLEMS 463; Young, The Aerial Inspection Plan and Air Space Sovereignty, Legal Problems 46.

11. My intention is to highlight the distinction between a unilateral, self-serving use (the actual probability) and a community-oriented, altruistic use (the potential possibility).

12. President Kennedy expressed this concern in his address to the 16th Session of the General Assembly: "The cold reaches of the universe must not become the new arena of an even colder war," N.Y. Times, Sept. 26, 1961.

13. Equivalent use does not mean identical use; thus a military use by A of outer space that serves its strategic needs legitimates a proportionate use by $\mathrm{B}$, given its peculiar strategic needs. Cf. the rather unconvincing suggestion of equivalence between Sputnik and U-2 overflights by Lipson, The Gagarin and Powers Flights, 17 Bulletin of the Atomic Scientists 274 (1961).

14. This formulation implicitly assumes that SamosMidas satellites operate in "outer space" and that outer 
space is outside of national territory. This issue will receive later consideration.

15. See Cooper, Letter to the Editor, 3 SPACEFlugrt, No. 2 at 99 (1961).

16. Id. at 100 .

17. See Wright, Legal Aspects of the U-2 Incident, 54 AM. J. INT'L L. 836 (1960).

18. An additional question can be asked: Is espionage illegal per se under international law or is it illegal only if there is some added element of illegality, such as an unauthorized penetration of the target state's territory? One can use this inquiry, as does Julius Stone, to suggest the legality of the Samos-Midas program under existing international law. This reasoning allows one to disregard the espionage feature in an appraisal of the legality of the contested activity. However, its effect is to destabilize interstate relations by resting a state's defensive authority upon technological change (i.e. ability to observe from outer space) rather than upon an analysis of the balance between the community interests favoring the use and the target state's interests in denying the use. Artificial legal categories cannot serve to determine the legal status of a contested quasi-military claim in an interdependent realm of conduct ( such as outer space), especially if the claim is laden with cold-war implications.

19. Katzenbach, Law and Lawyers in Space, 14 BulleTIN of THE ATOMIC ScIEntists 221, 222: "Whether it [satellite] is higher or lower is irrelevant to the objections an observer state would posit or the claims the observer would make."

20. Falk, Jurisdiction, Immunities, and Act of StateSuggestions for a Modified Approach, in Essays oN INTERNATIONAL JURISDiction (1961); Trautman, The Role of Conflicts Thinking in Defining the International Reach of American Regulatory Legislation, 20 Oніо ST. L. J. 586 (1961).

21. See especially McDougal, International Law, Power and Policy-A Contemporary Conception, 82 Hague RECUEIL 137 (1953); McDougal, The Policy-Science Approach to International Legal Studies, in INTERNATIONAL 
Law and the United Nations (Eighth Summer Institute, University of Michigan Law School, June 1955).

22. For instance, the controversial extra-territorial antitrust decisions: United States v. Timken Roller Bearing Co., 341 U.S. 593 (1951); United States v. Aluminum Co. of America, 148 F. 2d 416, 443 (2d Cir. 1946); see generally U.S. Attorney General's National Committee to Study the Antttrust Law Report 66-91 (1955).

23. Geneva Convention on the High Seas, U.N. Doc. A/CONF. 13/L. 53 and corr. 1 (1958) Article 5 (1): "Each State shall fix the conditions for the grant of its nationality to ships. . . . There must exist a genuine link between the State and the ship; in particular, the State must effectively exercise its jurisdiction and control in administrative, technical and social matters over ships flying its flag."

24. But this does relieve the claimant state of the duty to use a rational process of self-delimitation when it proposes to extend its competence by unilateral action; reciprocity and estoppel operate to limit the unilaterality of the process. See generally Falk, International Jurisdiction -Horizontal and Vertical Conceptions of Legal Order, 32 TEMP. L. Q. 295 (1959).

25. The probable inutility of these institutional alternatives is taken up later in this essay. Here the point is that a centralized legal order (e.g., domestic society in a modern state) solves controversies at the frontier by generating a new norm (legislation) or by extending an old norm (adjudication). Of course, this distinction is a caricature of the continuum that links judicial and legislative functions in an operating legal system.

26. Falk, Revolutionary Nations and the Quality of International Legal Order, in The World Revolution of Our Times, to be published in 1962 .

27. Of course, nuclear testing and missile development are military uses of outer space. However, they are neither continuing nor inconsistent with the non-military use of outer space during conditions of peace.

28. For the qualified assertion that "espionage of itself does not appear to constitute a violation of international 
law" see Note, Legal Aspects of Reconnaissance in Airspace and Outer Space, 61 Colum. L. Rev. 1074 (1961) (see especially note 1 at 1074). There seems to be authoritative doctrine available to support such a conclusion and considerable persuasive policy available to oppose it. An adequate analysis of the issue of "legality" would have to distinguish between information-gathering and various kinds of subversion. Espionage is increasingly part of the pattern of coercion roughly identified as "indirect aggression." The attempt to make the issue of legality rest upon the fact of war or peace seems to oversimplify the issue. For an excellent discussion of wartime espionage (and the like) see Baxter, So-Called "Unprivileged Belligerency"Spies, Guerrillas, and Saboteurs, 28 BRIT. Yв. INT'L L. 323 (1951).

29. See Kaplan \& Katzenbach, The Political FoundaTIONS OF INTERNATIONAL LAw 147-154 (1961); see also McDougal \& Burke, Crisis in the Law of the Sea-Community Perspectives versus National Egoism, in STUdIES IN World Public Order 844-911 (1960).

30. The distinction between exclusive and inclusive is borrowed from McDougal and Burke.

31. Fisher, Deputy for Restraint, 17 Bulletin of tHE Aтомic Scientists 272 (1961).

32. See Cheng, International Law and High Altitude Flights-Balloons, Rockets and Man-Made Satellites, in Legal Problems 141, 152-154; Trail Smelter Arbitration (United States v. Canada), 3 U.N. Rep. Int'l Arb. Awards 1905 (1938, 1941).

33. Note, National Sovereignty of Outer Space, 74 Harv. L. Rev. 1154, 1159-1167 (1961); Lipson \& Katzenbach, REport to the National Aeronautics and Space Administration ON THE LAW OF OUter Space 77-83 (1960); Jessup \& Taubenfeld, Controls for Outer Space 160-190 (1959).

34. Both excerpts are from Lipson, Outer Space and International LAw at 10 (RAND Paper P-1434, 1958).

35. For a brilliant discussion of this, see Herz, INTERnational Politics in the Atomic Age (1959).

36. N.Y. Times, Sept. 26, 1961. 
37. Reference here is to the problem of adjusting the international legal system-a development of Western European culture - to a plurality of contemporary normative traditions. Kunz, Pluralism of Legal and Value Systems and International Law, 49 AM. J. INT'L L. 370 (1955); NoRTHrop, The Taming of Nations (1952); Jenks, The ComMON LAW OF MANKIND 63-172 (1958). For some strictures upon attempts to solve the problems, see Falk \& Mendlovitz, Some Criticisms of C. Wilfred Jenks' Approach to International Law, 14 Rutgers L. Rev. 1, 4-16 (1959), and McDougal \& Lasswell, The Identification and Appraisal of Diverse Systems of Public Order, in STUdIES IN WorLD Public Order 3-41 (1960).

38. Fuller, Adjudication and the Rule of Law, and Morris, Peace through Law-The Role and Limits of Adjudication, Proceedings of the American Society of INTERNational Law 1, 15 (1960).

39. Note, National Sovereignty of Outer Space, 74 HaRv. L. Rev. 1154, 1174 (1961).

40. Case of the S.S. "Lotus," P.C.I.J., ser. A, No. 10 (1927).

41. That is, self-determined self-defense is a primary attribute of a decentralized legal order. Put differently, international law allows a state to characterize, in the first instance, its coercive conduct as "self-defense." This is partly a consequence of the absence of a definition of aggression.

42. Formalized expressions of public opinion-for instance, resolutions of censure in the United Nationsdeserve the status of a weak sanction in the international legal system. Over-analogy to the effectiveness of censure and ridicule in primitive societies is deceptive, as the Fall 1961 Soviet nuclear test explosions illustrate. We must not forget how much such sanctions depend upon a fairly high level of social integration among members of the community. A lack of just such integration is a major deficiency of the international order. Thus we must be careful about the analogies between decentralized primitive societies and the decentralized international legal order.

43. E.g., Stone, Aggression and World Order (1958); Stone, Quest for Survival (1961). 
44. However, it is likely that a particularized use of force would be treated as an exercise of police power. This would lead the controversy to avoid the more destabilizing rhetoric of "aggression" and "self-defense."

45. Hearings on International Control of Outer Space Before the House Committee on Science and Astronautics, 86th Cong., 1st Sess., 107 (1959) (testimony of Admiral Ward).

46. Becker, id. at 75 .

47. See Lipson, Outer Space and International Law at 12 (RAND Paper P-1434, 1958).

48. See criticism of Julius Stone for this tendency, in Falk, The Reality of International Law, 14 Worud Politics 353 (1962).

49. It should be stressed that this minimum Soviet commitment may turn out to be minimal.

50. See, op. cit. supra, note 45 at 2-3 (testimony of Senator Keating).

51. Cooper, Questions of Space Law, 3 SPACEFLight 95 (1961).

52. Ibid.

53. Cooper, Flight-Space, and the Satellites, 7 INT'L \& Cомp. L. Q. 82 (1958); Cooper, High Altitude Flight and National Sovereignty, 4 InT'L L. Q. 411 (1951); Cooper, Legal Problems of Upper Space, 1956 ProceEdings OF THE AMERican Society of International LaW 85; Cooper, Sovereignty in Space, Flying (January 1959).

54 . This is one way of expressing caution about the relevance of the International Court of Justice to the solution of a Midas-Samos controversy.

55. Kissinger, Nuclear Testing and the Problems of Peace, 37 Foreign Affairs 1 (1958).

56. N.Y. Times, Sept. 26, 1961. 


\title{
Espionage and Arms Control ${ }^{1}$
}

\author{
Roland J. Stanger *
}

\section{T}

1 HE UNITED STATES and Russia seem to agree on one crucial point. Neither we nor they can look to a military solution of the East-West conflict. All-out war, regardless of which side struck first, could result only in an intolerable level of mutual slaughter and destruction. Some millions of Americans and Russians would perhaps survive, in a biological sense. The words "The United States of America" and "The Soviet Union" would, however, have lost any meaningful content. What kind of society the survivors could fashion cannot be predicted and is, to many, unimportant. Three developments have brought this about: the atomic bomb, the hydrogen bomb, and the IсвM. We were first with the atomic bomb and the hydrogen bomb, the Russians with the ICBM. The scientific world is so much one world, however, that being first in anything can seemingly give only a passing advan-

- Professor of Law, Ohio State University. 
tage, and the three significant developments listed have all been to our long-run disadvantage. They have together cost us the advantages of our greater productive capacity and our geographical isolation. Our military power is enormously greater than ever before, and yet for the first time we are vulnerable to direct, devastating attack. This is the fault of no individual and no party. It is the result of the fact that $\mathrm{E}=\mathrm{MC}^{2}$, and man discovered that before he succeeded in creating a society which could live safely with that knowledge.

These developments have coincided with a marked deterioration in our relations with the Russians. Our response culminated, after a series of Russian aggressions, in the doctrine of massive retaliation. The moral implications of that doctrine troubled many of us. It was a threat to raise the horrors of war to a new dimension. Perhaps it is pointless to debate the morality of different forms of warfare. It may be that the distinctions between humane and inhumane weapons and between combatants and noncombatants have no validity. They are, however, very much a part of traditional Western morality. Conventional war, moreover, involved the gradual application of force. It was a war of attrition, in lives as well as property. Each side was free at any stage to decide it had had enough. Nuclear warfare, by substituting mass slaughter for attrition, deprives the belligerents of that choice.

For obvious reasons, we never defined just what encroachment on what American interest would lead us to apply the doctrine. We did not in fact apply it on several occasions when significant American interests 
were infringed. The doctrine may have been a colossal bluff. If anything made it credible, it was that we had dropped the bomb on Hiroshima.

Massive retaliation, if it was ever viable, is now obsolete. It became so when the Russians demonstrated they had the means to deliver thermonuclear warheads on our territory. Massive retaliation was a threat, designed to deter; but a deterrent is no better than it is credible. Massive retaliation, when it became a synonym for mutual suicide, ceased to be credible except as a response to a nuclear onslaught on the United States, or, perhaps, Western Europe. At that stage it would be largely pointless, except as an act of vengeance. Massive retaliation is, then, no longer a doctrine-like the Monroe Doctrine-which can be applied to protect American interests in one part of the world or another. It simply states the obvious fact that if we are subjected to an all-out attack, we will respond in kind, even if to do so would be irrational.

It can be said, however, that since both we and the Russians know we will both suffer unacceptable damage if either attacks, there is no risk that either side will deliberately start an all-out war. Below the nuclear threshold we should be able safely to engage in paramilitary operations, wars by proxy, and even limited wars. Professor Stone has pointed out that this is no mathematical certainty but a dangerous half-truth. It is nonetheless the theory on which we are now operating. Korea, Hungary, Indo-China, Quemoy and Matsu, the Congo, Cuba and Laos illustrate that it can work-for a time. History hardly suggests, however, that national 
leaders always behave rationally; that their decisions in times of international tension characteristically reflect an informed and dispassionate appraisal of the risks of war and its consequences. This is more than ever disquieting, since the consequences of a single miscalculation can be so catastrophic. Nor is miscalculation all we have to fear. There are other appalling risks in a world of Iсвм's and thermonuclear warheads. They exist because, given the destructive power of thermonuclear weapons, there is an enormous advantage to the first strike and, because of the speed of Iсвм's, the reaction time available to the defender is measured in minutes. The fact that a missile, once fired, cannot be recalled is a third element which augments the dangers of our situation.

The risks are many. There is the risk of an accident which could trigger a war. The accident could take any of several forms. One is of simple mechanical or human error. The incident in which a Sidewinder downed a B-52-though happily it did not involve nuclear weapons-is not reassuring. ${ }^{2}$ We can only hope that the Russian control systems are at least as foolproof as ours. Another is the false alarm, such as the flap, greatly magnified in the popular press, which occurred when our radar picked up the moon, rising over Norway. ${ }^{3}$ Still another is the possibility of a breach of firing discipline by a psychotic commander. One cannot have both a capacity for immediate retaliation and a completely centralized, safe control system.

Another major risk is that of escalation. It seems likely that any war between the major powers will, be- 
cause of the strong motivation to pre-empt-that is, to beat the other side to the draw-end in a thermonuclear exchange. If tactical nuclear weapons are used, escalation to strategic nuclear weapons seems even more likely. Present plans for the defense of Western Europe are said, nevertheless, to call for the use of tactical nuclear weapons from the outset.

Again, there is the risk of so-called catalytic war. An ambitious or desperate third country-China or Cuba, for example-could try to provoke a nuclear war between the major powers. And there are other risks, all of which increase each time another country joins the nuclear club. Also, there is always the possibility of some new development. Perhaps the most radical would be a real defense to the ICBM-an effective antimissile missile, ${ }^{4}$ for example. None is, apparently, now in sight. The side which finishes second in this particular race will have achieved unilateral nuclear disarmament without the help of pickets.

How one should rank these risks, and what, cumulatively, the odds are for a thermonuclear exchange in a year, or ten years, or twenty-five, is much debated. C. P. Snow gives us up to ten years. ${ }^{5}$ Other mortality tables give the human race a longer life expectancy, but still do not rate it an attractive insurable risk. It is not surprising, then, that the moralists and the strategists have joined forces and are working together on the problem of arms control. Those strategists, professional and amateur, who two or three short years ago were spinning out the intricacies of deterrence doctrine have since changed their focus. Every avenue was a blind 
alley, ending in an intolerable risk of annihilation. $\mathrm{E}=\mathrm{MC}^{2}$ is not the formula for national security.

I would add another factor: the threat which the nuclear stalemate poses to our democratic way of life. More and more of the vital decisions are made at the highest level-that is, by the president and his inner circle of advisers-behind closed doors, on the basis of information and for reasons which cannot be revealed or publicly debated. This is at present unavoidable but nonetheless unfortunate. But more than this is involved. For the first time in our country's history, we feel truly insecure, and we find it difficult to live with insecurity. We fear Russian power, and are frustrated that we cannot control the course of events in much of the world. We have translated our hatred for communist ideology into an implacable hatred for the Russians and the Chinese Communists. As a result, all our reactions to every issue tend to be in cold-war terms. One point of view is "pro-communist," another "anticommunist," whether the issue is landing the marines in Cuba, the minimum wage, or the fluoridation of our water supply. Democratic government cannot operate effectively in this atmosphere. Also, there is real danger that, if we should lose out to the Communists in other countries-Vietnam, Iran, Venezuela-our hatred, fear and frustrations will lead to an act of desperation that will touch off World War III.

What, then, of arms control as a way out?

When we still had a monopoly on nuclear weapons, we offered the Baruch plan. Its major premise was that 
effective control of fissionable materials required complete international control of their extraction, processing and use; that if fissionable materials in significant quantities came into national hands, control was not feasible. Our nuclear weapons are said to pack the equivalent of ten tons of TNT for every human being on earth. The Russian stockpile is presumably of a comparable order of magnitude. If the premise of the Baruch plan was sound, we have indeed had it.

Since the Baruch plan failed to win acceptance, our emphasis in disarmament negotiations has been on inspection. Perhaps we have over-emphasized its role, or at least failed to distinguish between the roles which inspection can play in different arms-control programs. One should keep in mind that inspection is not an end in itself. The immediate purpose of inspection is to obtain information, but the end is to determine whether an arms-control arrangement is being carried out. Even this is not, of course, the ultimate end. Verification is not control.

Information can be obtained either by open, authorized means, that is, by inspection, or by covert, unauthorized means, that is, by espionage. Our emphasis in current negotiations on inspection-which played a relatively minor role in disarmament arrangements in the pre-nuclear era-implicitly recognizes that espionage cannot now supply the adequate, reliable, usable information necessary to verify compliance with an arms-control arrangement. An inquiry into the difficult if not, indeed, insoluble problems involved in devising 
a workable inspection system is, then, in effect also an inquiry into the utility-almost by definition the lesser utility-of espionage in arms control.

Useful information can, broadly speaking, be about the intentions, the capabilities and the actions of the parties to an arms-control scheme. All such information will usually be relevant, but one kind or another may be crucial in a particular arms-control scheme. Inspection may yield information about intentions as well as capabilities and actions, but it is probably a fair generalization that reliable information as to intentions is the most difficult to obtain, information about acts the easiest. The point is worth keeping in mind in selecting from among possible arms-control schemes.

A test ban is a relatively promising arms-control arrangement, partly because the crucial information needed to know whether it is being observed is with respect to acts. It is seemingly agreed that nuclear weapons cannot be developed unless they are tested. We are satisfied that tests in the atmosphere can be effectively monitored. Our concern has been with underground tests and also tests in outer space. There is debate about how effective monitoring of underground tests by seismic instruments implemented by periodic on-the-spot checks can be. In the background of this debate is the issue of how high the reliability or confidence level of an inspection system must be. Some take the position that it must be completely reliable. The basic question is, however, whether the risk that the other side will not only try to evade, but will both escape detection and achieve significant results, is as great as the 
risk with no test ban. The choice is between risks, not between a risk and no risk. The other side will not try to evade until it weighs the likelihood and consequences of being caught against the possible but not certain gains.

It seems most unlikely that the Russians resumed testing and scuttled the test-ban negotiations because they feared that we would successfully evade a test ban. It seems doubtful also that the fear that the Russians would successfully evade a ban has been a major factor motivating American opposition to a test ban, even though, with their closed and our open society, evasion might be only difficult for them, whereas for us it would probably be impossible. The Russian announcement that they were resuming testing strongly suggests that they did not believe they could test effectively without detection, even in the absence of an agreed inspection system. It is much more likely that the Russians resumed testing, in part at least, because they believed they could gain more from weapons development than we could. American pressures to resume testing even before the Russians did so reflected the belief that we could gain more than they could. This is one form of a harder question. In an area so new and so little understood as nuclear warfare, what will be the impact on the two sides of a common restriction? Any negotiator will be troubled because, for reasons he may not discern, a restriction may have a greater impact on the military potential of his country than on that of the other country. The conservative approach is to refuse to agree to a restriction. This is, however, an elec- 
tion to continue the arms race rather than to try arms control. It has little to do with the feasibility of a test ban or the effectiveness of available inspection techniques in ensuring its observance.

A test ban also raises the issue, particularly for the Russians, of the side effects of inspection. This is the problem, referred to by Professor Stone, of how much other information-on conventional forces, nuclear weapons, civil defense, communications, and the restthe inspectors assigned to monitor the test ban would or might acquire. This is not a trivial point, to be dismissed as mere propaganda, nor one that arises only in the test-ban situation. Inspection techniques must be shaped as much as possible to take account of this factor. This seems more feasible with respect to a test ban than with other arms-control systems.

The role which inspection can play in other contexts than the test ban is quite different and, unhappily, much less impressive.

The haunting fear is of surprise attack. Protection against surprise attack is essentially a matter of receiving adequate warning, that is, notice of the other side's intention to attack. But it is precisely in providing reliable information regarding intention that inspection is least satisfactory. Physical inspection to protect against surprise attack, even if it meant constant surveillance of every launching site, missile-firing submarine, plane and train, would reveal only that every missile was ready for launching, as a good missile should be. It would not reveal whether there was any intention to launch. It has been said that a perfect inspection system with perfect 
communications could at most give ten minutes' added warning of a surprise attack. ${ }^{6}$

Inspection can, however, provide some protection against surprise attack, in the nature of long-run rather than immediate warning. Surprise attack is essentially a matter of intention, but it also involves capability. If one side's capabilities are concentrated in weapons with a low survival value-that is, weapons such as liquid-fueled, fixed-site missiles and manned bombers, which are likely to be destroyed in an enemy attack - the other side is warned to be on the alert against a surprise attack and could be moved to launch a forestalling, pre-emptive attack of its own. This is so because, since these weapons are not likely to be available to respond to an attack, their obvious purpose is for use in a surprise attack. If, on the other hand, one side's capabilities are concentrated in weapons with a high survival value-nuclear-powered, missile-launching submarines or solid-fueled missiles in silos-this constitutes some assurance to the other side that no surprise attack is planned. Something comparable can be said if one side's capabilities are concentrated in relatively low-accuracy, city-destroying weapons, rather than in high-accuracy, counter-force weapons capable of knocking out the other side's bomber bases and missile sites. The assurance is in either case far from perfect, since any weapon, no matter how high its survival value, can be used in a surprise attack against any target. It is still true, however, that the information which inspection might give as to total capabilities could be reassuring. Neither side is likely to launch a surprise at- 
tack unless it enjoys a marked overall superiority in weapons. Knowledge that the other side lacks such superiority can, then, lessen the fear of surprise attack and slow down the arms race. It seems likely that the information we gained regarding total Russian capabilities-perhaps thanks to the U-2 -led to the slowing down of our missile program.

The other risks inherent in the arms race, referred to earlier, are, in the present context, forms of surprise attack; and again inspection can play at best a limited role in minimizing any of them. The accidental firing of a nuclear weapon is, in a sense, an unintended and, hopefully, limited surprise attack-one that surprises both sides. If the control system of the side whose weapons are involved can't prevent an accident, inspectors can hardly do so, though they might conceivably get notice to the other side that an accident was just that. Resorting first to tactical nuclear weapons or to strategic nuclear weapons, in what began as a limited war, is again a form of surprise attack. It seems most doubtful that any inspection system could survive the outbreak of war, if for no other reason than that the side effects of inspection would then loom so large. ${ }^{7}$ If the inspection system did survive, it could perhaps reveal whether the armies in the field (whatever that term may now mean) had a nuclear capability, and possibly of what size; but again it could hardly give timely information of the key factor, intention to use the nuclear weapons. The risk of catalytic war again involves the element of surprise. However, although capability is necessary and intention relevant, the crucial factor is an 
act, e.g., the launching of a missile or missiles. Inspectors could conceivably convey to the prospective belligerents timely information as to the source of the attack, and that possibility could serve to deter a third country from trying the catalyst's role.

What has been said relates to the possible roles of inspection in minimizing the risks inherent in a fully armed world. At best the role is marginal and the risks awesome. Any significant reduction in those risks, to anything like a tolerable level, requires some measure of arms limitation. One possible arms-limitation scheme would leave each side with enough bombers and missiles to serve as a deterrent but not enough to make surprise attack an attractive gamble. The purpose of such a scheme would be so to reduce the destructive capabilities of the two sides that the continuance of our civilization would no longer depend wholly on their will. The role of inspection in implementing such a scheme would be almost entirely to ascertain total capabilities. It would be a crucial role, since the premium on evasion would be high. That premium would, moreover, rise as the permitted level of nuclear arms approached zero. If the permitted level of nuclear arms were, say, one hundred, and one side actually had one hundred five, the difference could be insignificant. If the permitted level were zero, and one side actually had five, the difference could be decisive.

The ultimate question is, then, whether inspection can give reliable information with respect to total capability. The stakes are such that the question calls for a long, hard look. One certainly shouldn't assume that, 
because inspection to ascertain capability is, in general, relatively more effective than inspection to ascertain intention, it does not present difficult and perhaps even insoluble problems.

It is probably true that a relatively simple inspection system-possibly even an open skies system-could, over a period, give reasonably reliable information as to the total capability of each side in missile-firing submarines, bombers, trains, and perhaps even liquidfueled, fixed-site missiles. Submarines must be built, and must dock somewhere at some time. Trains have to run on tracks. An air base can't be hidden, and perhaps the same is true of launching sites for liquidfueled missiles. Underground silos housing solid-fueled missiles are another matter entirely. We, with our open society, can't keep their location secret. The Russians, with their closed society, may be able to. The New York Times recently published a map of all our missile sites, existing and planned. ${ }^{8}$ Pravda has not published a comparable map showing Russian missile sites. So long as contracts for the construction of our missile bases are public contracts, let by competitive bidding, and labor disputes at the sites are news in this country, the Russians can learn their location without benefit of inspectors. The Russian system is different. Perhaps aerial inspection during construction would do the job, but after that it may be that no system of inspection would be effective. Moreover, if there is a limitation on nuclear weapons, capability can be as much a question of spare parts, pipe lines, production facilities, trained personnel and the like, as of missiles in position to be 
fired. Whether an inspection system, however complex, could yield reliable information on capability in this sense is highly debatable.

Inspection to determine capability also raises major problems with respect to side effects. An inspection system which gave reliable information as to capabilities would necessarily pinpoint every stationary target, e.g., missile sites, airfields, for the other side. It would not do so, however, with respect to missile-firing submarines and trains. Again, if one side knew precisely the capabilities of the other, it might risk a surprise attack, while if it didn't, it wouldn't. This should not be true, however, if the nuclear arsenal of each side is significantly limited. There could remain, however, the related risk that inspection might reveal a flaw in one side's weapons system, inherent or temporary, and known or unknown to it.

Doubt as to the possible effectiveness of physical inspection has led some to explore the possibilities of other kinds of inspection, ${ }^{9}$ such as the use of lie detectors. More interesting is the idea of an open scientific world, assured by recruiting, say, 10 per cent of the scientists in any laboratory from nationals of the other side. This would give a real impetus to the arms race, unless it were coupled with a general arms-limitation program. Again, an arms-limitation program might be implemented by persuading enough of the citizens of every country that their first duty was to see to it that their country lived up to the arms-limitation agreement, to the point that they would reveal any information they might have of a violation by their own country. Im- 
plementing this scheme of popular inspection would present its problems: How could the informants communicate with the inspectors? How could the informants be protected? How could the information so obtained be evaluated? The scheme would not, of course, be foolproof, but it could raise the risk of evasion to a very high level.

If general and complete disarmament, or even general and complete nuclear disarmament, is not possible, an arms-limitation program may be feasible which would limit each side's arsenal to missile-firing submarines and, perhaps, trains-that is, to mobile launching devices-and would be implemented by both a physical inspection system and inspection by populations. It would have the great advantages of removing nuclear weapons from centers of population and of minimizing the side effects of inspection. It may seem paradoxical to suggest eliminating all fixed-site, landbased missiles, when evasion of such a limitation is admittedly the most difficult to detect. It is, however, likely that inspection would be more effective, and evasion more difficult, if the prohibition were absolute rather than partial. Any evidence which suggested that one side was maintaining or trying to create any capability of this nature would then be unambiguous. Admittedly, there are risks in putting all one's nuclear eggs in one or two baskets, but they may well be less than the risks we now run.

It is time to consider inspection in implementation of arms control in the context of Professor Wright's and Professor Stone's illuminating discussions of espionage. 
Espionage is simply covert, unauthorized inspection. One cannot but be impressed by Professor Stone's argument that it is in the interest of all nations that espionage not be considered prohibited by international law per se. Professor Falk has, however, argued most effectively that unilateral acts of espionage are destabilizing, and hence particularly dangerous in a world in which both sides command so formidable a nuclear capacity. Moreover, the thrust of Professor Stone's argument carries one well beyond the potential ability of espionage to minimize the risks which confront mankind. Whether inspection-that is, open, authorized espionage-can effectively implement a significant measure of arms control is debatable. That it can be more effective than espionage seems, however, clear enough. Inspection is weak in the area of intention, but Korea, Hungary, Suez, Cuba, and Algiers suggest that traditional espionage is no stronger.

The significant point is, however, that intention is of maximum importance in a world engaged in an arms race. Arms control shifts the emphasis to capability, which is more easily verified. Those who fear the risks of arms control implemented by inspection should ponder the risks we now take in making crucial decisions on the basis of information obtained by espionage. We may have slowed down our missile program on the basis of information obtained from the U-2 flights. Information obtained by inspection would have been more reliable. More recently we made another crucial decision, on the basis of information obtained by espionage, as to the situation in Cuba. Our choice is 
between risks-not between the risks of arms control and the safety of an arms race.

The limitations imposed by traditional international law on the conduct of states have little relevance to the arms-control problem. International law does not forbid a country to arm itself with nuclear weapons, at least for defensive purposes-and who has them for any other purpose? It does not deny missile-firing submarines the right to run submerged anywhere on the high seas. It does not require nations to open their military secrets to inspectors, nor does it preclude their punishing those, citizens or aliens, who ferret out those secrets. Arms control can be achieved only through international agreements, though such agreements can be tacit.

International law and lawyers can contribute to achieving arms control primarily by suggesting the shape such agreements can take, and the means through which they can be implemented.

1. On the problem of arms control, see generally KIssinger, The Necessity for Choice (1960); Arms CoNtrol, Disarmament and National Security (Brennan ed. 1961); Arms Reduction, Program and Issues (Frisch ed. 1961); Schelling \& Halperin, Strategy and Arms Control (1961); Bull, The Control of the Arms Race (1961); Inspection for Disarmament (Melman ed. 1958).

2. N.Y. Times, April 8, 1961, p. 1. See also the report of the Bomarc incident, N.Y. Times, June 8, 1960, p. 2.

3. Hubbell, You Are Under Attack, Reader's Digest, April 1961, p. 37.

4. Baldwin, Race for the Anti-Missile Missile, N.Y. Times, April 15, 1962 (Magazine), p. 21. 
5. N.Y. Times, Dec. 28,1960 , p. 1.

6. Kissinger, Arms Control, Inspection and Surprise Attack, 38 Foreign AfFaIRS 557 at 562 (July 1960).

7. Cf. Schelling, Arms Control-Proposal for a Special Surveillance Force, 13 World Politics No. 1, p. 1 (Oct. 1960).

8. More recently the Times published a map of the area around Bitburg, in West Germany, showing the location of missile sites-described as "the only 'hardened' missile sites in Europe west of the Iron Curtain"-around the United States air base there. N.Y. Times, Sept. 23, 1961, p. 6.

9. See Inspection for Disarmament (Melman ed. 1958). 
THE FREE LIBRARY OF PHILADELPHIA
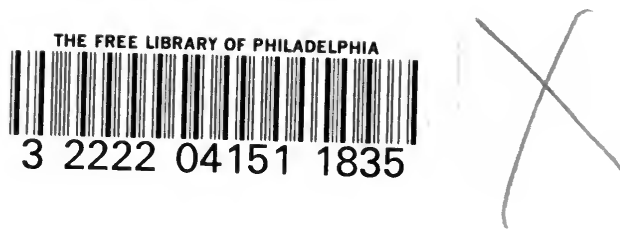

\section{Stack Ret}


<smiles>C1CCC1</smiles> 


\section{(1)

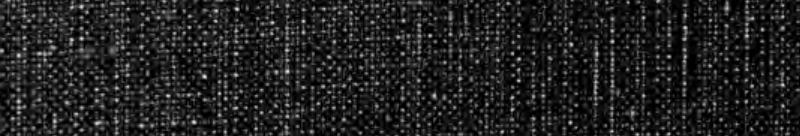

(1)

*

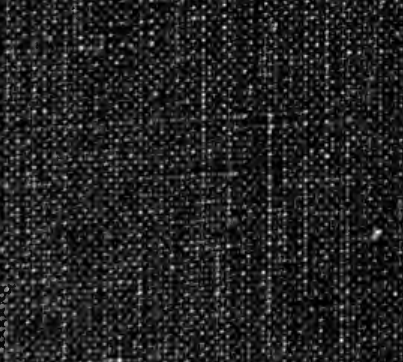

W.

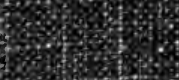

ing

(2)

$8 \%$

3.5.

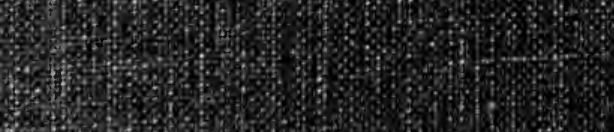

W.

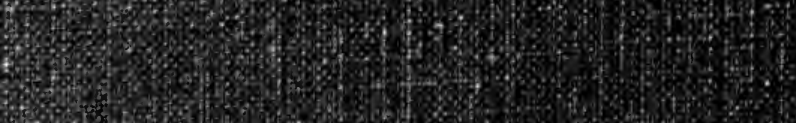

(5)

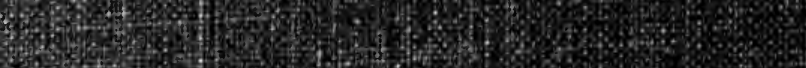

